\title{
RETROACTIVITY AND IMMIGRANT CRIMES SINCE ST. CYR: EMERGING SIGNS OF JUDICIAL RESTRAINT
}

\author{
VASHTI D. VAN WYKE ${ }^{\dagger}$
}

\section{INTRODUCTION}

Prior to 1996 if a permanent resident was convicted of a crime that subjected her to deportation, she was often eligible to apply for a waiver of deportation, known as 212(c) relief. ${ }^{1}$ A waiver of deportation was granted under 212(c) if the immigrant could show substantial equitable ties with the United States, including a U.S. citizen spouse or children, U.S. business ownership, and employment in the United States. $^{2}$ These 212(c) waivers were routinely granted in more than fifty percent of cases. ${ }^{3}$

In 1996, however, Congress overhauled immigration law through two bills-the Antiterrorism and Effective Death Penalty Act of 1996 (AEDPA $)^{4}$ and the Illegal Immigration Reform and Immigrant Responsibility Act of 1996 (IIRIRA). ${ }^{5}$ A central goal of the bills was to facilitate the deportation of immigrants convicted of crimes. To do this, AEDPA restricted and IIRIRA entirely eliminated the 212(c) waiver mechanism, meaning that permanent residents convicted of a greatly expanded list of crimes would be automatically deported, regardless of how deeply connected they were with the United States.

${ }^{\dagger}$ B.A. 1997, Wesleyan University; MALD 2001, Fletcher School of Law and Diplomacy, Tufts University; J.D. Candidate 2006, University of Pennsylvania. My thanks to Professor Kermit Roosevelt, Sarah Greenberger, Donald Conklin, and Abby Wright for reviewing and editing this Comment. All errors are my own.

${ }^{1}$ Immigration and Nationality Act (INA) of 1952, Pub. L. No. 82-414, § 212(c), 66 Stat. 181, 187 (codified at 8 U.S.C. §1182(c) (repealed 1996)).

${ }^{2}$ See infra note 36 and accompanying text (discussing factors that courts use to decide whether to grant a discretionary waiver of deportation).

${ }^{3}$ See infra notes 32-34 and accompanying text (citing data regarding the prevalence of 212(c) relief between 1989 and 1995).

${ }^{4}$ Pub. L. No. 104-132, 110 Stat. 1214 (codified as amended in scattered sections of 8, 18, 22, 28, 42 U.S.C.).

${ }^{5}$ Pub. L. No. 104-208, 110 Stat. 3009-546 (codified as amended in scattered sections of 8, 18 U.S.C.). 
While prospective elimination of 212(c) relief was politically controversial, it did not raise significant legal or constitutional questions. However, the Justice Department's subsequent interpretation of IIRIRA as eliminating 212(c) relief retroactively ${ }^{6}$ for immigrants who committed their crimes or were convicted of their crimes while 212(c) relief was still available created a clear conflict with the Supreme Court's retroactivity jurisprudence, embodied in Landgraf v. USI Film Products. ${ }^{7}$ After six years of litigation and the wrongful deportation of many permanent residents deported without recourse to a 212(c) waiver, the Supreme Court corrected the Justice Department's error, and the ratification of that error by many lower courts, in the landmark INS v. St. Cyr decision. ${ }^{8}$ In St. Cyr, the Supreme Court held that (1) the retroactivity framework of Landgraf functioned identically in immigration cases as in other cases; and (2) because Congress did not explicitly state that IIRIRA's repeal of 212(c) relief applied retroactively, the bill could not be used to deprive immigrants of 212(c) relief in a retroactive manner. ${ }^{9}$

While St. Cyr should have put an end to the controversy over 212(c) relief, lower courts have continued to permit the deportation of permanent residents without recourse to 212(c) relief, even though they committed their crimes, proceeded to trial after rejecting a plea bargain, or were convicted of their crimes prior to passage of IIRIRA. ${ }^{10}$ Lower courts have justified this retroactive application by narrowly limiting St. Cyr to its facts-the context of an accepted plea bargainand by giving only superficial consideration to Supreme Court precedent in determining the relevant prior act for retroactivity analysis. However, two recent decisions, Ponnapula v. Ashcroft $t^{11}$ and Olatunji v. Ashcroft, ${ }^{12}$ from the U.S. Courts of Appeals for the Third and Fourth Circuits respectively, suggest that lower courts may finally begin to fol-

\footnotetext{
${ }^{6}$ See In re Soriano, No. 3289, 1997 WL 33347804 (Att'y Gen. Feb. 21, 1997) (reporting a decision by Attorney General Reno that reversed a Board of Immigration Appeals opinion holding that the repeal of 212(c) was not retroactive).

${ }^{7} 511$ U.S. 244 (1994); see also infra Part II.A.2 (discussing the significance of the Landgraf decision).

833 U.S. 289 (2001).

${ }^{9}$ See id. at 315-25 (holding, based on the Landgraf two-part test, that an impermissible retroactive effect would be created by removing access to 212(c) relief).

${ }^{10}$ See infra Part II.B (providing examples of lower courts' misapplication of Landgraf in immigration cases).

${ }^{11} 373$ F.3d 480 (3d Cir. 2004).

${ }^{12} 387$ F.3d 383 (4th Cir. 2004).
} 
low the fundamental dictate of St. Cyr, which is to fully apply the Landgraf retroactivity analysis to cases involving immigrants.

The persistent failure of most lower courts to faithfully apply retroactivity analysis to 212 (c) cases is important in at least two respects. First, on the level of individual justice, the failure means that permanent residents who actually qualify to apply for 212(c) waivers are still being summarily deported, leaving behind U.S. citizen spouses and children, businesses, employment, and community ties.

Second, on the level of coherent jurisprudence, the failure means that the Supreme Court's retroactivity framework has been bifurcated-there is one set of retroactivity rules primarily applied to corporate defendants, and a second, much harsher set of retroactivity rules applied to immigrants convicted of crimes. ${ }^{13}$ Particular concern is raised by the fact that harsher rules are being applied to a small, unpopular, and politically weak group of people. After all, one of the primary arguments against retroactive laws, voiced originally by the Framers of the Constitution, ${ }^{14}$ is that such laws can be used by the government to target unpopular and weak groups, by heaping consequence upon consequence well after those individuals have acted. Just such a result has materialized in the case of immigrants and 212(c) relief. Conforming the lower courts' 212(c) decisions to the

${ }^{13}$ See infra Part III.E (discussing the continuing double standard in retroactivity analysis). From a legal realist perspective, an interesting phenomenon has developed in the area of 212(c) retroactivity. Conservative judges, who generally support law enforcement measures, see Ward Farnsworth, Signatures of Ideology: The Case of the Supreme Court's Criminal Docket, 104 MiCH. L. REV. 67, 74, 84-85 (2005) (illustrating the tendency of the conservative members of the Rehnquist Court to vote against prisoners), have actually led the way toward full application of the Landgraf framework to 212(c) cases - which, in practice, serves to benefit immigrants convicted of crimes. For example, Justice Thomas has urged a rethinking of the exemption of civil laws from the Ex Post Facto clause in Eastern Enterprises v. Apfel, 524 U.S. 498, 538-39 (1998) (Thomas, J., concurring). See also infra note 71 (contextualizing Justice Thomas's beliefs about retroactive civil laws). In addition, Judge Luttig, who is generally identified as a conservative, see Peter M. Shane, Federalism's "Old Deal": What's Right and Wrong with Conservative Judicial Activism, 45 VILL. L. REv. 201, 235 (2000), authored the Fourth Circuit's Olatunji decision, 387 F.3d 383, which struck down the retroactive application of an IIRIRA provision. Also, Justice Scalia's concurrence in Martin v. Hadix, 527 U.S. 343, 363 (1999), offers the most probing review of the concept of retroactivity. Meanwhile, Janet Reno, Attorney General to Democratic President Bill Clinton, was responsible for originally applying the repeal of 212(c) retroactively to all immigrants, regardless of when their crimes were committed. See supra note 6 and accompanying text (describing Reno's interpretation of IIRIRA as eliminating 212(c) relief retroactively).

${ }^{14}$ See infra notes 63-64 and accompanying text (discussing the Federalists' advocacy for a ban on retroactivity in the Constitution). 
Supreme Court's basic retroactivity framework will go far in preventing this invidious result.

This Comment argues that, since St. Cyr, the lower courts have not followed the Supreme Court's mandate to fully apply the Landgraf framework to 212(c) cases in two important ways. First, they have failed to recognize that retroactivity analysis is fundamentally concerned with statutory construction (i.e., whether the language of the statute indicates its temporal scope and the class to which the statute applies), coupled with a presumption against retroactivity. Instead, they have incorrectly introduced an individual reliance requirement into the Landgraf test. Thus, even where the law would not apply to a broad class of people because of the presumption against retroactivity, lower courts have found that individual members of that class have not "earned" the right to be protected from retroactive application because they did not actually rely on the prior state of the law.

Despite the lower courts' misinterpretation of St. Cyr, the recent circuit court decisions in Ponnapula v. Ashcroft and Olatunji v. Ashcroft have made significant strides toward full application of Landgraf to immigration cases by holding that reliance is not a requirement for a finding of impermissible retroactive effect. ${ }^{15}$ Given the holdings of St. Cyr and Landgraf, this is clearly the correct conclusion and should be followed by the remaining circuits. Nonetheless, a split among the circuits has developed on this question, with the Third ${ }^{16}$ and Fourth ${ }^{17}$ holding that individual reliance is not a requirement for a finding of impermissible retroactivity, and the Second ${ }^{18}$ and Ninth ${ }^{19}$ Circuits holding that an individualized assessment is appropriate. Given this split and the question's importance for retroactivity jurisprudence

${ }^{15}$ See Ponnapula, 373 F.3d at 491 ("The Supreme Court has never required actual reliance or evidence thereof in the Landgraf line of cases, and has in fact assiduously eschewed an actual reliance requirement."); Olatunji, 387 F.3d at 388-89 (“[W]e hold that reliance (whether subjective or objective) is not a requirement of impermissible retroactivity and that the government's notice is insufficient to overcome the impermissibly retroactive effect of IIRIRA on Olatunji's guilty plea.").

16 Ponnapula, 373 F.3d at 491.

${ }_{17}$ Olatunji, 387 F.3d at 388-89.

${ }^{18}$ See Rankine v. Reno, 319 F.3d 93, 100 (2d Cir. 2003) ("Because those aliens who went to trial prior to the elimination of $\S 212$ (c) cannot show that they altered their conduct in reliance on the availability of such relief, we hold that IIRIRA's repeal of $\$ 212$ (c) relief is not impermissibly retroactive as applied to them.").

${ }^{19}$ See Kelava v. Gonzales, 410 F.3d 625, 629 (9th Cir. 2005) ("We have cabined St. Cyr to the plea context, because of the alien's reliance on existing law in that situation."). 
more broadly, the Supreme Court should step in to resolve the question.

Second, the lower courts have failed to follow the Landgraf line of cases on the question of which past conduct is protected from retroactive application of new laws. Currently, in the 212(c) context, no circuit views the immigrant's commission of the crime as the essential conduct for analysis. This means that if a permanent resident committed her crime in 1990, for example, while 212(c) relief was still available, but was not convicted until after 1996, she would not be deemed eligible to apply for a waiver of deportation. This consensus has developed despite the fact that under a complete Landgraf analysis, and particularly when considering the decisional rules offered in Martin v. Hadix, ${ }^{20}$ the commission of the crime is the only logical point of analysis to determine an impermissible retroactive effect. Under current Supreme Court jurisprudence, if an immigrant committed a crime while 212(c) relief was still available, she should be deemed eligible to apply for a waiver of deportation; to hold otherwise would create an impermissible retroactive effect.

\section{LEGAL BACKGROUND}

\section{A. Statutory Evolution of 212(c) Relief}

For at least a century, federal immigration control laws have provided for the deportation of noncitizens, including permanent residents, who have been convicted of certain crimes. ${ }^{21}$ Before the 1996

${ }^{20} 527$ U.S. 343, 357-58 (1999). Two potential decisional rules are offered in Martin $v$. Hadix to determine which past act is relevant for retroactivity analysis. The majority and dissenting opinions both suggest the following rule: At what point could the party have avoided all the consequences of the new law? Id. at 357-58, 369. Justice Scalia's concurring opinion suggests asking what activity the statute was intended to regulate. Id. at 363. The rules proposed in Martin v. Hadix are discussed in more detail later in Part III.C.

${ }^{21}$ The definition of the crimes that render immigrants eligible for deportation has changed over the years. For example, the Immigration and Nationality Act (INA) of 1917, Pub. L. No. 64-301, § 3, 39 Stat. 874, 875-78 (amended 1952) (repealed 1996), made crimes "involving moral turpitude" deportable offenses. See INS v. St. Cyr, 533 U.S. 289, 294 (2001) (citing the 1917 Act and noting its operation). The Anti-Drug Abuse Act (ADAA) of 1988, Pub. L. No. 100-690, 102 Stat. 4469, 4469-70 (codified at 8 U.S.C. § 1227(a) (2) (A) (iii)), added deportation for conviction of an "aggravated felony," which included murder and any drug trafficking crimes. By 1994, the INA provided for deportation of immigrants convicted of two crimes of moral turpitude, or one crime of moral turpitude within five years of entry plus a conviction for a crime for which a sentence of one year or more may be imposed. See 8 U.S.C. $\S$ 1227(a) (2) (A) (i) (I-II) (Supp. V 1994) (establishing grounds for deportation). But 
changes to federal immigration law, deportation was not mandatory or automatic; immigration statutes in force prior to 1996 each contained a mechanism for discretionary waivers of deportation if the immigrant possessed certain qualifications or other equities warranted a waiver. $^{22}$ The Immigration Act of 1917 included a discretionary waiver process through the Secretary of Labor, ${ }^{23}$ while the more modern statutes gave that power to the Attorney General through the 212 (c) mechanism. ${ }^{24}$

Before 1990, permanent residents ${ }^{25}$ who were convicted of a deportable offense and had lived continuously in the United States for seven years were permitted to apply for a waiver of deportation from the Attorney General. ${ }^{26}$ Changes to 212(c) in 1990 further restricted eligibility for such waivers. ${ }^{27}$ These changes meant that immigrants

these provisions all provided for a 212(c) waiver of deportation under meritorious circumstances. For a discussion of the development of 212(c) legislation over the last century, see St. Cyr, 533 U.S. at 294-97.

${ }^{22}$ See INA of $1917 \S 3$ (providing for discretionary relief from deportation as determined by the Secretary of Labor); INA of 1952, Pub. L. No. 82-414, § 212(c), 66 Stat. 181, 187 (1952) (amended 1990) (repealed 1996) (providing for discretionary relief from deportation as determined by the Attorney General). The discretionary waivers in both the 1917 Act and 1952 Act explicitly regulated only exclusion proceedings, where a lawfully admitted immigrant who temporarily proceeded abroad sought readmission into the United States. Both Acts, however, were interpreted to apply to deportation proceedings as well. See, e.g., In re L., 1 I. \& N. Dec. 1, 6 (B.I.A. 1940), available at 1940 WL 7544 (holding under the 1917 Act that deportation proceedings were governed by the INA's standards for exclusion of immigrants from readmission); In re Silva, 16 I. \& N. Dec. 26, 30 (B.I.A. 1976), available at 1976 WL 32326 (holding the same under the 1952 Act). The BIA is the appellate body that reviews decisions made by immigration judges.

${ }^{23}$ See INA of $1917 \S 3$ (giving the Secretary of Labor discretionary power to waive deportation).

${ }^{24}$ See INA of $1952 \S 212$ (c) (designating the Attorney General as the official possessing the discretionary waiver power).

${ }^{25}$ This Comment refers to lawful permanent residents as immigrants, LPRs, or permanent residents. In legal statutes and scholarly writing, another common designation for an LPR is "permanent resident alien." However, that term is avoided here because of the negative connotations of the word "alien." See, e.g., Victor C. Romero, Expanding the Circle of Membership by Reconstructing the "Alien": Lessons from Social Psychology and the "Promise Enforcement" Cases, 32 U. MiCH. J.L. REFORM 1, 47 (1998) (discussing the pejorative connotations of the word).

${ }^{26}$ See INA of $1952 \S 212$ (c) (permitting a permanent resident to apply for a waiver if she could show seven years of continuous residency).

${ }^{27}$ Congress amended the INA in 1990 to remove 212(c) relief from immigrants convicted of aggravated felonies who had served at least 5 years in jail. INA of 1990, Pub. L. No. 101-649, tit. V, §511(a), 104 Stat. 5048, 5052 (1990) (codified at 8 U.S.C. $§$ 1182(c)) (repealed 1996); see INS v. St. Cyr, 533 U.S. 289, 297 (detailing changes in 212 (c) eligibility). 
were not permitted to apply for 212(c) relief if they had been convicted of an "aggravated felony" as defined by 8 U.S.C. $§ 1101$ (a) (43) $(1994)^{28}$ and, in addition, had actually served at least five years in prison. $^{29}$

Prior to IIRIRA's passage, the 212(c) relief mechanism worked in the following manner: If an immigrant who had lived continuously in the United States for seven years was convicted of a deportable offense, she could then be ordered deported by the Immigration and Naturalization Service (INS). ${ }^{30}$ After receiving an order to appear to answer the deportation charge, she was eligible to apply for 212(c) relief from the Attorney General if she had not been convicted of an aggravated felony, or had been convicted of an aggravated felony but had served less than five years in prison. ${ }^{31}$ The immigrant would then make her case for the waiver at an administrative hearing before an Immigration Judge (IJ). There was a "strong likelihood that such relief would be granted" by the IJ. ${ }^{32}$ One study showed that 212(c) relief was granted in $51.5 \%$ of final decisions in cases between 1989 and $1995,{ }^{33}$ and more than 10,000 immigrants received waiver grants during that same period. ${ }^{34}$

The IJ's decision whether to grant 212(c) relief was guided by a longstanding Board of Immigration Appeals (BIA) standard. ${ }^{35}$ Factors to be considered included: "[T] he seriousness of the offense, evidence of either rehabilitation or recidivism, the duration of the alien's

${ }^{28}$ The statute lists twenty-one categories of crime that are defined as "aggravated felonies," including, inter alia, murder, drug trafficking, and illicit dealing in firearms.

${ }^{29}$ See INA of $1990 § 511$ (amending 8 U.S.C. $§ 1182$ (c)); see also St. Cyr, 533 U.S. at 297 (discussing changes implemented by 1990 statute).

${ }^{30}$ See e.g., Mapp v. Reno, No. CV-99-4240, 2000 WL 1911424, at*2 (E.D.N.Y. July 14,2000 ) (noting the procedural steps required in an immigration case involving deportation and $212(\mathrm{c}))$.

${ }^{31}$ See $\$ 1182$ (c) (1994) (repealed 1996) (setting forth 212(c) eligibility). This fiveyear cap on the amount of time an immigrant could serve in prison for an aggravated felony and still be eligible to apply for 212(c) relief will be referred to as the "timeserved" provision in this Comment.

${ }^{32}$ Ponnapula v. Ashcroft, 373 F.3d 480, 486 (3d Cir. 2004); see also St. Cyr, 533 U.S. at 296 n.5 (discussing the high rate of 212 (c) grants).

${ }^{33}$ Julie K. Rannik, The Anti-Terrorism and Effective Death Penalty Act of 1996: A Death Sentence for the 212(c) Waiver, 28 U. MIAMI INTER-AM. L. REV. 123, 137 n.80 (1996); see also Mattis v. Reno, 212 F.3d 31, 33 (1st Cir. 2000) (“[I]n the years immediately preceding the statute's passage, over half the applications were granted.").

${ }^{34}$ See Rannick, supra note 33, at 137 n.80 (listing the number of 212(c) waivers granted annually from 1989 to 1995 ).

${ }^{35}$ The oft-cited source for the standard is In re Marin, 16 I. \& N. Dec. 581 (B.I.A. 1978), available at 1978 WL 36472. 
residence, the impact of deportation on the family, the number of citizens in the family, and the character of any service in the Armed Forces." ${ }^{36}$ If the crime was particularly serious, the immigrant would have to show more equities to outweigh the harm of the offense. ${ }^{37}$ The policy underlying the availability of relief was that once an immigrant had paid for her crime within the criminal justice system, the United States would benefit more from her continued presence than from her deportation, which would cause disruptions to her family in the United States, her business or employer, and her other community ties. ${ }^{38}$

On April 24, 1996, Congress enacted the Antiterrorism and Effective Death Penalty Act of 1996 (AEDPA). ${ }^{39}$ Section $440(\mathrm{~d})$ of AEDPA excluded numerous classes of immigrants from eligibility for 212(c) relief, including immigrants "ordered deported because of a conviction for an aggravated felony, for a drug conviction, for certain weapons or national security violations, and for multiple convictions involving crimes of moral turpitude." ${ }^{40}$ AEDPA also removed the five-year "time served" qualification of the 1990 INA. ${ }^{41}$ Getting rid of this provision meant that immigrants who were convicted of acts that technically qualified as aggravated felonies, but who received only a suspended sentence because the circumstances of their crime rendered them virtually blameless, would now receive mandatory deportations. ${ }^{42}$

${ }^{36}$ St. Cyr, 533 U.S. at 296 n.5 (noting that these criteria are set forth in In re Marin, 16 I. \& N. Dec. at 585-85).

${ }^{37}$ See Anjali Parekh Prakash, Changing the Rules: Arguing Against Retroactive Application of Deportation Statutes, 72 N.Y.U. L. REV. 1420, 1430 n.74 (1997) ("Where the offense is extremely severe, a heightened showing of 'unusual or outstanding equities' is required.").

${ }^{38}$ See Kati L. Griffith, Perfecting Public Immigration Legislation: Private Immigration Bills and Deportable Lawful Permanent Residents, 18 GEO. IMMIGR. L.J. 273, 288 (2004) (“A careful consideration of the factors allowed immigration judges to weigh the LPR's overall value to her family and community against any potential danger posed to society.").

Pub. L. No. 104-132, 110 Stat. 1214 (1996) (codified as amended in scattered sections of $8,18,22,28,42$ U.S.C.).

${ }^{40}$ St. Cyr, 533 U.S. at 297 n.7.

${ }^{41}$ AEDPA $\$ 440$.

${ }^{42}$ See James F. Smith, United States Immigration Law as We Know It: El Clandestino, the American Gulag, Rounding Up the Usual Suspects, 38 U.C. DAVIS L. REV. 747, 769 (2005) ("Many common misdemeanor offenses, such as petty theft (shoplifting) or simple assault, qualify as aggravated felonies because they are punishable by a maximum of one year, even if the common state sentencing schemes of probation or community service and a suspended sentence are imposed.”). 
On September 30, 1996, just five months after the passage of AEDPA, Congress acted to further expedite deportation of immigrants convicted of crimes, by enacting IIRIRA. ${ }^{43}$ Among other changes, IIRIRA repealed 212(c) relief completely, ${ }^{44}$ and replaced it with a much narrower relief mechanism called cancellation of removal. ${ }^{45}$ A permanent resident is only eligible for cancellation of removal if she has not been convicted of an "aggravated felony," regardless of the amount of time she served in jail. ${ }^{46}$

Further increasing the restrictive nature of the new law, IIRIRA redefined the term "aggravated felony" to encompass scores of new offenses, including misdemeanors and low-level felonies ${ }^{47}$ that are not understood to be aggravated felonies in any other context. ${ }^{48}$ In addition, Congress made this redefinition of "aggravated felony" explicitly retroactive to crimes committed before passage of IIRIRA, a result that has been upheld, and properly so, by the courts. ${ }^{49}$ These IIRIRA

${ }^{43}$ See supra note 5 and accompanying text.

${ }^{44}$ IIRIRA $\S 304(\mathrm{~b})$.

${ }^{45}$ IRIIRA $\$ 304(\mathrm{a})(3)$. IIRIRA also replaced the term "deportation" with the term "removal," making "cancellation of removal" the semantic equivalent of a "waiver of deportation." Id.

${ }^{46} I d$. (outlining the eligibility requirements for cancellation of removal).

${ }^{47}$ See IIRIRA $\$ 321$ (codified at 8 U.S.C. $\$ 1101$ (a) (43)); see also Ponnapula v. Ashcroft, 373 F.3d 480, 486 (3d Cir. 2004) ("The definition of 'aggravated felony' has been retroactively expanded to include dozens more offenses, including misdemeanor and low-level felony offenses."). This congressional redefinition of "aggravated felony," though contrary to statutory precedent and normal usage, has been upheld by the courts. See id. at 486 (noting that courts have upheld this expanded definition and providing examples in which misdemeanors were held to be aggravated felonies). Therefore, minor offenses have resulted in the deportation of immigrants who, in many cases, had lived in the United States almost their entire lives and had no ties to the country to which they were deported. See, e.g., United States v. Pacheco, 225 F.3d 148, 149-50, 154-55 (2d Cir. 2000) (holding that a misdemeanor theft of a video game punished by a one-year suspended sentence is an aggravated felony under the redefinition and affirming an order of deportation of the immigrant to a country in which he had not lived since he was six years old); United States v. Graham, 169 F.3d 787, 792-93 (3d Cir. 1999) (holding that a misdemeanor petty larceny offense is an aggravated felony under the redefinition).

${ }^{48}$ See Graham, 169 F.3d at 792-93 (3d Cir. 1999) (holding that, in fact, misdemeanors qualify as felonies under the redefinition, and reasoning that Congress simply made a drafting error in choosing the term "aggravated felony").

${ }^{49}$ See 8 U.S.C. $\$ 1101$ (a) (43) (2000) ("Notwithstanding any other provision of law (including any effective date), the term applies regardless of whether the conviction was entered before, on, or after [September 30, 1996]."). The retroactive application of the definition of "aggravated felony" to convictions obtained before the passage of IIRIRA is permissible because (1) Congress explicitly mandated the retroactive application; (2) deportation is interpreted to be a civil, not a criminal penalty, and so is not subject to ex post facto protections; and (3) the retroactive application is not otherwise 
changes made immigrants automatically deportable if they had been convicted of crimes that fell within the new, very broad definition of "aggravated felony."

\section{B. Early Interpretations of 212(c) Relief and Retroactivity}

Following the passage of AEDPA, questions immediately arose about the scope of the legislation's strict limits on 212(c) eligibilitydid the new limits apply only prospectively or retroactively as well? The BIA held, in a 7-5 decision, that AEDPA's 212(c) eligibility limits did not apply retroactively to cases already pending before the courts. ${ }^{50}$ Attorney General Janet Reno reversed that holding pursuant to her power to review BIA decisions ${ }^{51}$ and held instead that AEDPA's 212(c) changes applied retroactively as well. ${ }^{52}$ Basing her opinion on the retroactivity framework of Landgraf, the Attorney General held that applying AEDPA's restrictions to immigrants already convicted of their crimes did not have an impermissible retroactive effect because (1) the decision of whether to grant a 212(c) waiver of deportation was a question of prospective relief, and "[p] ast conduct is relevant only insofar as it may shed light on the respondent's right to remain in the U.S."; ${ }^{53}$ and (2) AEDPA only changed jurisdictional aspects of 212(c) relief-i.e., who was eligible to apply for relief, which is purely discretionary-rather than any substantive right to receive the relief. The Attorney General held that removal of a merely discretionary opportunity, as opposed to a vested right, did not create a retroactive effect. ${ }^{54}$

The Attorney General's cramped interpretation, which was rejected in full by the Supreme Court in St. Cyr, permitted the automatic

unconstitutional. Cf. Landgraf v. USI Film Prods., 511 U.S. 244, 280 (1994) ("If the statute would operate retroactively, our traditional presumption teaches that it does not govern absent clear congressional intent favoring such a result.").

${ }^{50}$ See In re Soriano, 21 I. \& N. Dec. 516 (B.I.A. 1996), available at 1996 WL 426888, rev'd, No. 3289, 1997 WL 33347804 (Att'y Gen. Feb. 21, 1997).

${ }^{51}$ The Attorney General's authority to review BIA decisions at the time of In re Soriano was provided for in 8 C.F.R. § 3.1(h) (1997). Today, the Attorney General maintains the power to review BIA decisions under revised regulations located at 8 C.F.R. $§ 1003.1(\mathrm{~h})(2002)$.

${ }^{52}$ See In re Soriano, 1997 WL 33347804 (reporting a decision by Attorney General Reno that reversed a Board of Immigration Appeals opinion holding that the repeal of 212 (c) was not retroactive).

${ }^{53}$ Nadine K. Wettstein, Attorney General Issues Soriano § 212(c) Decision, 74 INTERPRETER RELEASES 326, 326 (1997).

${ }^{54}$ See id. at 327 (noting that the "Attorney General rejected the argument that AEDPA $\S 440$ (d) implicates a substantive right to relief from deportation”). 
deportation of immigrants who committed their crimes while 212(c) was still available, as well as immigrants who made legal and tactical decisions about their criminal defense while 212(c) was still available, but who had not yet received a final decision on their 212(c) application. ${ }^{55}$

Litigants challenged the Attorney General's decision in the circuit courts from 1997 until the St. Cyr decision in 2002. ${ }^{56}$ Until the Supreme Court intervened in St. Cyr, the circuits were split as to whether AEDPA's restrictions on and IIRIRA's repeal of 212(c) had an impermissible retroactive effect as applied to immigrants who were convicted prior to the statutory changes. ${ }^{57}$ The circuits agreed, however, that no

${ }^{55}$ See id. (summarizing the practical results of the Attorney General's interpretation).

${ }^{56}$ See Daniel Kanstroom, St. Cyr or Insincere: The Strange Quality of Supreme Court Victory, 16 GEO. IMMIGR. L.J. 413, 413 n.2 (2002) (acknowledging six attorneys and the ACLU Immigrants Rights Project who "labored so long and hard" to reverse the Attorney General's opinion in Soriano, which culminated in the St. Cyr decision).

${ }^{57}$ The circuit courts that sided with the Attorney General on this issue generally reiterated the two arguments made in In re Soriano. The Third Circuit's decision in DeSousa v. Reno, 190 F.3d 175 (3d Cir. 1999), is representative of this group of decisions. In DeSousa, the court held, first, that there was significant textual support to conclude that Congress intended to make AEDPA's limitations on 212(c) relief retroactive to pre-enactment convictions. See id. at 186 ("By implication then, we can assume that Congress intended for $\S 440(\mathrm{~d})$, which amended $\S 212(\mathrm{c})$, to apply to all convictions, regardless of their date."). Second, DeSousa concluded that no impermissible retroactive effect would be caused by applying AEDPA's 212(c) limitations to previous convictions. Id. at 187 . The court so concluded for two reasons. First, the consequences of the criminal act were the same both before and after passage of AEDPA, namely "possible criminal sanctions and deportation." Id. (quoting Scheidemann v. INS, 83 F.3d 1517, 1523 (3d Cir. 1996)). Second, the court held that the only relevant change made by AEDPA involved the scope of the Attorney General's discretion to grant relief, and "[1]ike statutes altering the standards for injunctive relief, this change has only a prospective impact." Id. (quoting Scheidemann, 83 F.3d at 1523).

On the other side of the debate was the Second Circuit's decision in the St. Cyr case, which the Supreme Court later affirmed. See St. Cyr v. INS, 229 F.3d 406, 417-18 (2d Cir. 2000), aff'd, 533 U.S. 289 (2001). The Second Circuit discussed the complexity of the split among the circuits, noting that the Third, Fifth, and Tenth Circuits adopted the INS view that AEDPA's limitations on 212(c) eligibility did apply to preenactment convictions; the First and Ninth Circuits held that AEDPA's limitations did not apply to immigrants who can show they pleaded guilty in reliance on the availability of 212(c) relief; the Fourth Circuit adopted a blanket rule that AEDPA's limitations did not apply to any immigrant whose conviction was based on a guilty plea; and the Seventh Circuit held that AEDPA's limitations applied to pre-enactment guilty pleas, unless an immigrant "had conceded deportability, despite a colorable defense" in reliance on the availability of the 212(c) waiver. The cases catalogued by the Second Circuit's St. Cyr opinion are found at Mattis v. Reno, 212 F.3d 31, 38 (1st Cir. 2000); Tasios v. Reno, 204 F.3d 544, 552 (4th Cir. 2000); Magana-Pizano v. INS, 200 F.3d 603, 612 (9th Cir. 1999); Requena-Rodriguez v. Pasquarell, 190 F.3d 299, 306 (5th Cir. 1999); DeSousa 
impermissible retroactive effect was created by applying the new statutes to immigrants who committed their crimes before the changes, but were convicted after the changes. ${ }^{58}$

\section{RETROACTIVITY ANALYSIS AND ITS (MIS)APPLICATION IN THE IMMIGRATION CONTEXT}

Fundamentally, retroactivity analysis in the civil context is a question of statutory construction, with a strong presumption against retroactive application. A civil statute applies retroactively only where the statute itself clearly so requires; if the statute is silent on the question of temporal scope, then the new law will only be applied prospectively. ${ }^{59}$ In the immigration context, however, many lower courts have incorrectly introduced a subjective reliance requirement into this analysis. This is inconsistent with how statutory construction and the presumption against retroactivity work. Once a court determines that the scope of a statute is not expressly retroactive as to a class of people-i.e., people who undertook a certain conduct before enactment of the new law-then that entire class is protected from the new law by the presumption against retroactivity. To require proof of subjective reliance is to engage in judicial legislation; the court is choosing to apply a statute retroactively to certain individuals, even though the statute does not expressly mandate such application as to the entire class.

\section{A. The Framework for Retroactivity Analysis}

Retroactivity has been disfavored since the founding of the American legal system. In the civil context, this disfavor is embodied in the Landgraf decision and is expressly required in the immigration context by St. Cyr.

190 F.3d at 185; Jurado-Gutierrez v. Greene, 190 F.3d 1135, 1147 (10th Cir. 1999); Turkhan v. Perryman, 188 F.3d 814, 827 (7th Cir. 1999); and LaGuerre v. Reno, 164 F.3d 1035, 1041 (7th Cir. 1998).

${ }_{58}$ The most widely cited justification for this holding is one sentence of unsupported dicta from LaGuerre, 164 F.3d at 1041. "It would border on the absurd to argue that these aliens might have decided not to commit drug crimes, or might have resisted conviction more vigorously, had they known that ... when their prison term ended, [if] ordered deported, they could not ask for a discretionary waiver of deportation." Id. See infra Part III.A for a detailed discussion of this issue.

59 See Landgraf v. USI Film Prods., 511 U.S. 244, 286-87 (1994) (Scalia, J., concurring) (" $[\mathrm{T}]$ here exists a judicial presumption, of great antiquity, that a legislative enactment affecting substantive rights does not apply retroactively absent clear statement to the contrary."). 


\section{The Historical Roots of Retroactivity}

The notion that the government should not retroactively attach new legal consequences to past acts was a central founding legal principle of the United States, with roots in English common law and earlier Roman law, and has persisted as a broad and settled principle of modern jurisprudence. ${ }^{60}$ Retroactivity is constitutionally impermissible in the criminal context under the Ex Post Facto Clause ${ }^{61}$ and is heavily disfavored in the civil context. ${ }^{62}$

Opposition to retroactive rulemaking was of great importance to the Framers of the Constitution. ${ }^{63}$ Professor Natelson suggests that the issue of retroactivity was "central to the constitutional bargain" and that the Federalists were staunch advocates for including a ban on retroactivity in the Constitution. ${ }^{64}$

${ }^{60}$ Justice Scalia has argued that the "principle that the legal effect of conduct should ordinarily be assessed under the law that existed when the conduct took place has timeless and universal human appeal." Kaiser Aluminum \& Chem. Corp. v. Bonjorno, 494 U.S. 827, 855 (1990) (Scalia, J., concurring). The longstanding nature of this principle is clear, as noted by one early New York case: "It is a principle of the English common law, as ancient as the law itself, that a statute, even of its omnipotent parliament, is not to have a retrospective effect." Dash v. Van Kleeck, 7 Johns. 477, 503 (N.Y. Sup. Ct. 1811). Roman legal scholars were opposed to retroactive applications of the law; one Roman legal maxim held that "[t]he penalty for a past wrong is never increased ex post facto.” See Robert G. Natelson, Statutory Retroactivity: The Founders' View, 39 IDAHO L. REV. 489, 499-501 (2003) (discussing the opposition to retroactivity under Roman law). Antiretroactivity was of central importance to the Framers during the drafting of the U.S. Constitution. See id. at 499 (noting the importance of opposition to ex post facto laws for many of the Framers). Antiretroactivity was emphasized in the Federalist Papers. See The Federalist No. 44, at 278-79 (James Madison) (Clinton Rossiter ed., 1961) ("Bills of attainder, ex-post-facto laws, and laws impairing the obligation of contracts are contrary to the first principles of the social compact and to every principle of sound legislation.”). The Supreme Court has also acknowledged the historic roots of antiretroactivity in its seminal civil retroactivity decision. See Landgraf, 511 U.S. at 265 ("[T] he presumption against retroactive legislation is deeply rooted in our jurisprudence, and embodies a legal doctrine centuries older than our Republic.").

${ }^{61}$ See U.S. CONST. art. 1, § 9, cl. 3 ("No Bill of Attainder or ex post facto Law shall be passed.”); see also Calder v. Bull, 3 U.S. (3 Dall.) 386, 391 (1798) (Chase, J.) (holding that the constitutional prohibition on ex post facto laws applies only to criminal cases).

${ }^{62}$ See Landgraf, 511 U.S. at 272 ("[W]hile the constitutional impediments to retroactive civil legislation are now modest, prospectivity remains the appropriate default rule.").

${ }^{63}$ See Natelson, supra note 60, at 491-94 (noting the centrality of retroactivity issues to the framing of the Constitution).

${ }^{64}$ See id. at 492-93. Natelson argues that the Federalists compromised on the issue of retroactivity in order to obtain ratification. Id. at 527. While many Federalists thought the Ex Post Facto Clause should apply in both criminal and civil contexts, they 
Justice Story, sitting on the Circuit Court of New Hampshire in Society for Propagation of the Gospel $v$. Wheeler, articulated his influential definition of retroactivity, which the Landgraf Court adopted: ${ }^{65}$ "Upon principle, every statute, which takes away or impairs vested rights acquired under existing laws, or creates a new obligation, imposes a new duty, or attaches a new disability, in respect to transactions or considerations already past, must be deemed retrospective."

The serious policy concerns presented by retroactive laws are obvious and oft-repeated. These include a fear of government abuse, ${ }^{67}$ upsetting settled expectations of individuals and groups, ${ }^{68}$ the danger of using retroactive laws to injure unpopular groups, ${ }^{69}$ and predictability concerns. ${ }^{70}$

compromised on this issue by representing that "the Ex Post Facto Clauses did not bar all forms of retroactivity, but only strongly retroactive criminal laws." Id. Therefore, Natelson concludes that Calder v. Bull, which restricted the Ex Post Facto Clause to criminal laws, was probably correctly decided. Id. at 494. The Landgraf decision notes that James Madison opposed retroactive laws as "contrary to the first principles of the social compact, and to every principle of sound legislation." Landgraf, 511 U.S. at 267 n.20 (quoting THE FEDERALIST NO. 44 (James Madison)). Madison also argued that retroactive laws were particularly pernicious in that they could benefit the "influential" class over the "more industrious and less informed part of the community." Id. (quoting THE FEDERALIST NO. 44 (James Madison)).

${ }^{65}$ See Landgraf, 511 U.S. at 268-69 (approving of Justice Story's definition).

${ }^{66}$ Soc'y for Propagation of the Gospel v. Wheeler, 22 F. Cas. 756, 767 (No. 13,156) (Story, Circuit Justice, C.C.N.H. 1814). The Landgraf opinion notes that the Supreme Court has formulated the definition of retroactivity in various ways, but all have retained a "similar functional conceptions" to Justice Story's definition of retroactivity. Landgraf, 511 U.S. at 269. The Landgraf opinion collects several iterations of the definition of a retroactive law, including a law that "changes the legal consequences of acts completed before its effective date," id. at 269 n.23 (quoting Weaver v. Graham, 450 U.S. 24, 31 (1981)); one that gives "a quality or effect to acts or conduct which they did not have or did not contemplate when they were performed," $i d$. (quoting Union Pac. R.R. Co. v. Laramie Stock Yards Co., 231 U.S. 190, 199 (1913)); and one that "takes away or impairs vested rights acquired under existing laws, or creates a new obligation, imposes a new duty, or attaches a new disability," id. (quoting Sturges v. Carter, 114 U.S. 511, 519 (1884)). Note that the terms "retrospective" and "retroactive" are used interchangeably in retroactivity jurisprudence.

${ }^{67}$ See, e.g., Weaver, 450 U.S. at 29 (suggesting that the Ex Post Facto Clause "restricts governmental power by restraining arbitrary and potentially vindictive legislation").

See, e.g., Landgraf, 511 U.S. at 265 ("Elementary considerations of fairness dictate that individuals should have an opportunity to know what the law is and to conform their conduct accordingly; settled expectations should not be lightly disrupted."); see also Gen. Motors Corp. v. Romein, 503 U.S. 181, 191 (1992) ("Retroactive legislation presents problems of unfairness that are more serious than those posed by prospective legislation, because it can deprive citizens of legitimate expectations and upset settled transactions.").

${ }^{69}$ See, e.g., Landgraf, 511 U.S. at 266 (“[The legislature's] responsivity to political 
In Calder v. Bull the Supreme Court held that the Ex Post Facto Clause expressly prohibits retroactive criminal laws, but not retroactive civil laws. ${ }^{71}$ Because the Supreme Court has long held that deportation is only a civil remedy rather than a criminal penalty, ${ }^{72}$ even when the deportation is based on a criminal conviction, ${ }^{73}$ the Ex Post

pressures poses a risk that it may be tempted to use retroactive legislation as a means of retribution against unpopular groups or individuals.”). Landgraf also cites several other authorities on this point, including City of Richmond v. J.A. Croson Co., 488 U.S. 469, 513-14 (1989) (Stevens, J., concurring) ("The constitutional prohibitions against ... ex post facto laws and bills of attainder reflect a valid concern about the use of the political process to punish or characterize past conduct of private citizens."); James v. United States, 366 U.S. 213, 247 n.3 (1961) ("[Retroactive laws may have] a purpose not to prevent dangerous conduct generally but to impose by legislation a penalty against specific persons or classes of persons.”); and Charles B. Hochman, The Supreme Court and the Constitutionality of Retroactive Legislation, 73 HARV. L. REV. 692, 693 (1960) (noting that a retroactive law "may be passed with an exact knowledge of who will benefit from it"). Landgraf, 511 U.S. at 267 n.20.

${ }^{70}$ On this point, Landgraf cites Professor Munzer: "The rule of law . . . is a defeasible entitlement of persons to have their behavior governed by rules publicly fixed in advance." Landgraf, 511 U.S. at 265 n.18 (quoting Stephen R. Munzer, A Theory of Retroactive Legislation, 61 TEX. L. REV. 425, 471 (1982)). Traditionally, the focus of predictability concerns has been on commercial transactions, contracts, and property. See $i d$. at 271 (noting the historic focus of retroactivity jurisprudence on commercial topics). Landgraf highlights eight Supreme Court decisions that applied the presumption against retroactivity in the commercial context. See id. at $271 \mathrm{n} .25$ (citing inter alia United States v. Sec. Indus. Bank, 459 U.S. 70, $79-82$ (1982); Holt v. Henley, 232 U.S. 637 (1914); and Twenty per Cent. Cases, 87 U.S. (20 Wall.) 179, 187 (1874)).

${ }^{71}$ See Calder v. Bull, 3 U.S. (3 Dall.) 386, 390-91 (1798) (Chase, J.) ("I do not think [the Ex Post Facto Clause] was inserted to secure the citizen in his private rights, of either property, or contracts."); see also Landgraf, 511 U.S. at 266 n.19 (reaffirming that Calder v. Bull governs whether the Ex Post Facto Clause applies to civil laws). While the division between civil and criminal law in Calder has become a matter of faith for the courts, Justice Thomas has expressed disdain for the Calder holding and an interest in revisiting the entire question of what laws are prohibited under the Ex Post Facto Clause. See E. Enters. v. Apfel, 524 U.S. 498, 539 (1998) (Thomas, J., concurring) ("In an appropriate case, therefore, I would be willing to reconsider Calder and its progeny to determine whether a retroactive civil law that passes muster under our current Takings Clause jurisprudence is nonetheless unconstitutional under the Ex Post Facto Clause.").

${ }^{72}$ See, e.g., Harisiades v. Shaughnessy, 342 U.S. 580, 594 (1952) (holding that the Ex Post Facto Clause poses no restriction to the civil remedy of deportation proceedings); Galvan v. Press, 347 U.S. 522, 531 (1954) (same); see also Marcello v. Bonds, 349 U.S. 302, 314 (1955) (declining to overturn Galvan or Harisiades).

${ }^{73}$ See, e.g., United States v. Koziel, 954 F.2d 831, 834-35 (2d Cir. 1992) (noting that it is well-established that a deportation proceeding for a convicted immigrant is not a criminal penalty but a civil procedure to determine the right to remain in the country (citing Harisiades, 342 U.S. at 594)). However, persuasive arguments have been made that deportation based on a criminal conviction is clearly punishment, and so should be subject to the Ex Post Facto Clause's restrictions. Third Circuit Judge Sarokin wrote the following: 
Facto Clause does not directly govern questions of retroactivity and deportation, including the repeal of 212(c) relief. Nevertheless, decisions regarding retroactivity in the civil context routinely cite to Ex Post Facto Clause cases as persuasive authority, ${ }^{74}$ because the Clause demonstrates the general disdain our system has for retroactive laws.

\section{Landgraf and Its Progeny}

In Landgraf v. USI Film Products, the Supreme Court provided the modern framework for analysis of retroactivity questions in the civil context. ${ }^{75}$ Landgraf's two-part test is fundamentally a rule of statutory construction with a strong presumption against retroactivity, unless Congress has expressly mandated otherwise. ${ }^{76}$ Landgraf's test does not include an individualized assessment of whether a particular defendant has relied on the prior state of the law or whether any unfairness would result from a retroactive application in her particular case. Fairness and reliance are only important in that they are the reason for the presumption against retroactivity; unless Congress expressly requires a retroactive application of the statute, the courts presume that Congress did not intend to act unfairly by applying a law retroactively to a class of people who acted before the new law took effect.

The legal fiction that deportation following a criminal conviction is not punishment is difficult to reconcile with reality, especially in the context of this case. Mr. Scheidemann entered this country at age twelve; he has lived here for thirty-six years; he has been married to an American citizen for twenty-four years; he has raised three children all of whom are American citizens; his elderly parents are naturalized citizens; two of his four siblings are naturalized American citizens, and all four of them reside permanently in the United States; he has no ties to Colombia, the country to which he is to be deported; and he has fully served the sentence imposed upon him. If deportation under such circumstances is not punishment, it is difficult to envision what is.

Scheidemann v. INS, 83 F.3d 1517, 1527 (3d Cir. 1996) (Sarokin, J., concurring).

Others have argued that the Due Process Clause limits retroactive application of deportation laws. See, e.g., Nancy Morawetz, Rethinking Retroactive Deportation Laws and the Due Process Clause, 73 N.Y.U. L. REV. 97, 160-61 (1998) (arguing that IIRIRA's retroactive deportation rules violate the Due Process Clause because they lack the necessary rationales to justify such harsh retroactive provisions).

${ }^{74}$ See, e.g., Hughes Aircraft v. United States ex rel. Schumer, 520 U.S. 939, 948 (1997) (citing the Ex Post Facto Clause for support in a civil retroactivity case); Landgraf, 511 U.S. at 266 (same).

${ }^{75}$ See, e.g., Ponnapula v. Ashcroft, 373 F.3d 480, 487 (3d Cir. 2004) (noting that Landgraf is the "principal authority" governing civil retroactivity cases).

${ }^{76}$ See Landgraf, 511 U.S. at 270, 272-73 (suggesting that the stated rule is a means of interpreting statutes to "coincide with legislative and public expectations"). 
It is helpful to understand the facts of Landgraf. The case arose out of a sexual harassment and retaliation suit against Ms. Landgraf's employer, USI Film Products. ${ }^{77}$ The district court found that she had been sexually harassed, but that the harassment was not sufficiently severe to justify her decision to quit. ${ }^{78}$ Therefore, her termination did not violate Title VII, and she was not eligible for equitable relief in the form of back pay. ${ }^{79}$ At the time of the district court decision, Title VII only authorized equitable relief, leading the trial court to dismiss her action despite its finding that she had been sexually harassed. ${ }^{80}$ However, while Landgraf's appeal was pending, the Civil Rights Act of 1991 was signed into law. ${ }^{81}$ The new Civil Rights Act allowed plaintiffs who proved harassment to recover compensatory and punitive damages as well, and permitted any party to request a jury trial if damages were claimed. $^{82}$ Based on this new provision, Landgraf argued on appeal that her case should be remanded to the trial court for a jury trial on damages. ${ }^{83}$

The Supreme Court held, in an 8-1 decision, ${ }^{84}$ that applying the new damages provisions of the Civil Rights Act of 1991 to conduct (the sexual harassment) that occurred before the effective date of the law, would be impermissibly retroactive, given that Congress did not explicitly state that the damages provision should be applied retroactively.

The Court reached this conclusion by applying a two-part test. ${ }^{86}$ Step one asks "whether Congress has expressly prescribed the statute's proper reach." ${ }^{87}$ If Congress made the statute's scope expressly retroactive, then it must be applied retroactively, and there is "no need to

${ }^{77}$ Id. at 248

${ }^{78} I d$.

${ }^{79} I d$. at $249,252$.

${ }^{80}$ Id. at 249 .

${ }^{81}$ Pub. L. No. 102-166, 105 Stat. 1071

${ }^{82} I d . \S 102$.

${ }^{83}$ Landgraf, 511 U.S. at 249.

${ }_{85}^{84}$ Justice Blackmun dissented in the case. Id. at 294 (Blackmun, J., dissenting).

${ }^{85}$ See id. at 286 (majority opinion) ("[W]e have found no clear evidence of congressional intent that $\$ 102$ of the Civil Rights Act of 1991 should apply to cases arising before its enactment....").

${ }^{86} I d$. at 280. This test has been accepted unanimously by the Court several times since Landgraf. See, e.g., Martin v. Hadix, 527 U.S. 343, 352 (1999) (applying Landgraf's two-step analysis); Hughes Aircraft v. United States ex rel. Schumer, 520 U.S. 939, 946 (1997) (holding that absent evidence of clear congressional intent, the statute will not have retroactive effect under the Landgraf analysis).

${ }^{87}$ Landgraf, 511 U.S. at 280. 
resort to judicial default rules." 88 If Congress did not make clear the temporal reach of the statute, then the court must determine "whether the new statute would have retroactive effect, that is, whether it would impair rights a party possessed when he acted, increase a party's liability for past conduct, or impose new duties with respect to transactions already completed." pose new legal consequences on past acts, then the "traditional presumption" against retroactive application without "clear congressional intent" would prohibit the retroactive effect. ${ }^{90}$

The Landgraf test is, thus, one of statutory construction with a strong presumption against retroactivity, absent a statement by Congress expressly prescribing the statute's temporal reach. A civil statute may be made retroactive by Congress if it so desires, because the Ex Post Facto Clause is not a bar in the civil context. ${ }^{91}$ However, absent a clear showing that the statute's scope extends to past acts, the presumption against retroactivity will void any such application of the law. The courts' role is to faithfully implement the law as written by Congress, be it retroactive or prospective, and where the scope of the statute is unclear, a court may only permit prospective application, because of the strong disfavor for retroactive laws. ${ }^{92}$

The Landgraf two-part test is only concerned with statutory construction (i.e., what is the scope of the statute and to which class does this statute apply?) rather than with considerations of fairness or reliance by individual parties. The Court's decision in Landgraf did not rest on the effects of the statute as applied to the facts of that particu-

${ }^{88} I d$.

${ }^{89} \mathrm{Id}$.

${ }^{90} \mathrm{Id}$.

91 See id. at 266 n.19 (noting the inapplicability of the Ex Post Facto Clause to anything other than "penal legislation"). Presumably, the Due Process Clause would place some sort of limitation on the freedom Congress has to apply consequences retroactively in the civil context. See Morawetz, supra note 73, at 160-61 (suggesting that the Due Process Clause is an independent limit to retroactivity).

${ }^{92}$ The Court notes that its presumption against retroactivity in the civil context is soundly rooted in a "long line of cases" that "span two centuries," including Bowen v. Georgetown University Hospital, whose straightforward rule the Court cites approvingly: "[C] ongressional enactments and administrative rules will not be construed to have retroactive effect unless their language requires this result." Landgraf, 511 U.S. at 272 (quoting Bowen v. Georgetown Univ. Hosp., 488 U.S. 204, 208 (1988)). The Court also notes that the jurisprudence that supports the antiretroactivity presumption has largely, but not exclusively, involved provisions "affecting contractual or property rights." Landgraf, 511 U.S. at 271. Indeed, the Court highlights an early Chinese immigration case, Chew Heong v. United States, 112 U.S. 536, 559 (1884), as an example of the presumption's use outside the commercial context. 
lar case. The presumption against retroactivity means that once it is theoretically possible that the reliance interest of any member of a class could be upset by application of the statute (i.e., that there is a retroactive effect), then the statute is read to exclude every member of that class.

"Fairness" is only a component of the analysis insofar as it is the basis for the presumption against retroactivity. ${ }^{93}$ Congress is permitted to be "unfair" by crafting explicitly retroactive laws if it so decides; but if Congress does not clearly mandate retroactivity, the Court will presume the statute does not retroactively add legal consequences to past acts, because the Court presumes that Congress does not act in an unfair manner without explicitly saying it is doing so.

Indeed, the Landgraf Court rightly noted that concerns about "lack of fair notice," "suspect legislative purpose," and "fairness" were "muted" on the particular facts of the case because sexual harassment was legally proscribed at the time the harassment occurred. ${ }^{94}$ Even though fairness to the employer, USI Film, was not a concern, a retroactive effect was still not permissible. Clearly then, the Court's decision was not based on an individualized consideration of fairness.

The same is true in the Supreme Court's next important civil retroactivity decision, Hughes Aircraft Company v. United States ex rel. Schumer. ${ }^{95}$ In a unanimous decision, the Hughes Court fully adopted

${ }^{93}$ As the Landgraf Court stated:

Requiring clear intent assures that Congress itself has affirmatively considered the potential unfairness of retroactive application and determined that it is an acceptable price to pay for the countervailing benefits. Such a requirement allocates to Congress responsibility for fundamental policy judgments concerning the proper temporal reach of statutes, and has the additional virtue of giving legislators a predictable background rule against which to legislate.

Landgraf, 511 U.S. at 272-73. The Court is equally clear when it notes that "[ $\mathrm{t}]$ he presumption against statutory retroactivity has consistently been explained by reference to the unfairness of imposing new burdens on persons after the fact." Id. at 270.

${ }^{94}$ Id. at 282. The Civil Rights Act of 1964 had already made sexual harassment unlawful; sexual harassment discrimination was already subject to monetary liability (back pay) under the 1964 version of the Act. Id. Further, compensatory damages do not "smack of a 'retributive' or other suspect legislative purpose" because they seek to make the victim whole. Id. Thus, the Court concluded that compensatory damages are "not in a category in which objections to retroactive application on grounds of fairness have their greatest force." Id. Yet, despite this muted concern with fairness, the Court still found that application of the amended Act's compensatory damages provision to conduct occurring before enactment of the statute was retroactive because it would "affect[] the liabilities of defendants," would have "an impact on private parties' planning," and would "attach an important new legal burden to that conduct." Id. at $282-83$.

${ }^{95} 520$ U.S. 939 (1997). In Hughes, the Court embraces Landgraf's presumption 
the Landgraf framework. Nowhere in the opinion does the Hughes Court discuss the defendant's reliance on the new law, nor does it consider whether applying the later law to past conduct would be unfair to the defendant, Hughes. ${ }^{96}$ Instead, the Court finds an impermissible retroactive effect because applying the new law to past conduct would "attach[] a new disability," "create a new cause of action," and "deprive Hughes of [a] defense." "99 The Hughes Court used the same test for retroactive effect set out in Landgraf: whether new legal consequences have been attached to past conduct. ${ }^{100}$

against retroactive legislation, calling it a "time-honored presumption" to be applied "unless Congress has clearly manifested its intent to the contrary." Id. at 946. The decision is notable because it is unanimous, quite short, and absolutely embraces the crystal clear rules of statutory construction set out in Landgraf, a clarity that is lost in the lower court decisions on 212 (c) retroactivity.

${ }^{96}$ A summary of the facts of Hughes follows. In 1989, William J. Schumer filed a qui tam suit against Hughes Aircraft, under the False Claims Act (FCA), 31 U.S.C. $\S 3730$ (b) (2000). The FCA allowed private individuals to sue parties, on behalf of the government, for submitting false claims to the government. Congress amended the FCA in 1986 to expand the opportunity to bring qui tam actions. False Claims Amendments Act of 1986, Pub. L. No. 99-562, § 3, 100 Stat. 3153. Prior to the 1986 amendment, if the government possessed the information on which the claim was based, the government alone could file suit. 31 U.S.C. $\$ 3730$ (b) (4) (1982). After the 1986 amendment, however, prior knowledge by the government no longer barred commencement of a qui tam claim unless the information had been "publicly disclosed" and the suit "was not brought by an original source of the information." Hughes, 520 U.S. at 946 . Schumer sued under the 1986 amendment to the FCA. The allegedly false claims were submitted by Hughes to the government between 1982 and 1984, several years before passage of the 1986 amendment. The Court undertook a Landgraf two-step analysis and determined that (1) there was no indication that Congress intended the amended provision to apply retroactively, $i d$., and (2) applying the amendment in this case would have an impermissible retroactive effect by removing a defense available to Hughes prior to the 1986 amendment, id. at 951-52. Therefore, the Court held that the District Court should have dismissed Schumer's qui tam suit because it was based on information the government possessed, which provided Hughes with a full defense under the 1982 version of the statute. Id. at 952.

${ }_{97}$ Hughes, 520 U.S. at 948 (quoting Landgraf, 511 U.S. at 269).

${ }^{98} I d$.

${ }^{99} I d$. at 951-52.

${ }^{100}$ See Hughes, 520 U.S. at 947 (affirming Landgraf as the controlling "formulation[] to describe ... [the] definition for presumptively impermissible retroactive legislation"); see also Landgraf, 511 U.S. at 269-70 ("The court must ask whether the new provision attaches new legal consequences to events completed before its enactment."). 
While Landgraf's test for retroactive effect is clear, ${ }^{101}$ some lower courts have introduced "reliance" as a component of the test for retroactive effect in the immigration context. ${ }^{102}$ Lower courts have based this muddying of Landgraf's clear test on a misreading of one sentence of that opinion. After stating the rule for determining retroactive effect, Landgraf notes the difficulty that courts may have in determining retroactive effect. ${ }^{103}$ Then, the Court offers guidance to lower courts, suggesting they should trust their instincts in making this determination. The exact sentence, often misused by lower courts, ${ }^{104}$ reads as follows: "However, retroactivity is a matter on which judges tend to have 'sound ... instinct[s],' and familiar considerations of fair notice, reasonable reliance, and settled expectations offer sound guidance."105

Contrary to lower courts' interpretation, the Court here has not set up an individualized, as-applied test for retroactive effect, but merely offers lower courts signposts for detecting when a retroactive effect as to an entire class has occurred. If applying a new rule to a past act has the potential of operating in an unfair way as to members of a class (i.e., defendants who committed their act prior to the new law) then the statute creates a retroactive effect. There is no requirement

101 The Landgraf decision notes that the Court's definition of retroactive effect has also remained consistent over time. See Landgraf, 511 U.S. at 269 ("Though the formulas have varied, similar functional conceptions of legislative 'retroactivity' have found voice in this Court's decisions and elsewhere."). The Court cites several opinions to support this assertion, including Society for Propagation of the Gospel $v$. Wheeler, 22 F. Cas. 756, 767 (No. 13,156) (Story, Circuit Justice, C.C.N.H. 1814) (defining a retroactive statute as one that "takes away or impairs vested rights acquired under existing laws, or creates a new obligation, imposes a new duty, or attaches a new disability"); Miller $v$. Florida, 482 U.S. 423, 430 (1987) ("A law is retrospective if it "changes the legal consequences of acts completed before its effective date." (quoting Weaver v. Graham, 450 U.S. 24, 31 (1981))); and Union Pacific Railroad Co. v. Laramie Stock Yards Co., 231 U.S. 190, 199 (1913) (noting that a retroactive statute gives "a quality or effect to acts or conduct which they did not have or did not contemplate when they were performed"). Landgraf, 511 U.S. at 268-69. The Landgraf Court phrases the definition in this way: a statute is retroactive if it "would impair rights a party possessed when he acted, increase a party's liability for past conduct, or impose new duties with respect to transactions already completed." Id. at 280.

102 See, e.g., Rankine v. Reno, 319 F.3d 93, 100 (2d Cir. 2003) (asking whether "the petitioners chose to go to trial in reliance on the availability of $\$ 212$ (c) relief").

${ }^{103}$ See Landgraf, 511 U.S. at 270 ("Any test of retroactivity will leave room for disagreement in hard cases, and is unlikely to classify the enormous variety of legal changes with perfect philosophical clarity.").

${ }^{104}$ See infra Part II.B (detailing the continued misapplication of the Landgraf decision by lower courts).

${ }^{105}$ Landgraf, 511 U.S. at 270 (citation omitted) (quoting Danforth v. Groton Water Co., 178 Mass. 472, 476 (1901)). 
for an individual member of that class to prove that she would suffer an unfairness were the new law to be applied to her in particular.

In the 212(c) context, some lower courts have held that the illegality of the prior act is sufficient notice to preclude a later finding of retroactive effect. ${ }^{106}$ However, both Landgraf and Hughes make clear that this reasoning is incorrect. ${ }^{107}$ Actual notice that some behavior is proscribed and illegal, and so carries with it criminal and civil consequences, is irrelevant to the question of whether the new law attaches new legal consequences to past acts. Just because an act is proscribed does not mean that the penalty for that act can be increased retroactively.

The only dispositive test for retroactive effect under Landgraf and its progeny is not fairness or reliance by individual parties, but whether new legal consequences have been attached to the past conduct of a class of litigants. The Landgraf rule is crystal clear; unfortunately, the analysis by some lower courts on this issue in the 212(c) context, has been less so.

\section{The Court's Decision in St. Cyr}

The Supreme Court's 2002 decision in INS v. St. Cyr was a watershed event in immigration law because it reversed six years of incorrect application of Landgraf in the 212(c) context. ${ }^{108}$ The pre-St. Cyr interpretation of the law-by the Attorney General and many lower federal courts-was so out of line with the mandate of Landgraf that St. Cyr has been rightly termed an "easy case." ${ }^{.09}$ Unfortunately, the

${ }^{106}$ See e.g., Scheidemann v. INS, 83 F.3d 1517, 1523 (3d Cir. 1996) ("In this case, the consequences of petitioner's criminal conduct were clear at the time of that conduct and they remain unchanged today. He was subject to possible criminal sanctions and deportation.").

${ }^{107}$ See Hughes Aircraft v. United States ex rel. Schumer, 520 U.S. 939, 947-48 (1997) (holding that the illegality of the act-submission of a false claim to the government-is not relevant to the question of whether a retroactive effect has occurred); Landgraf, 511 U.S. at 283 n.35 (noting that even if conduct is "morally reprehensible or illegal," the presumption against retroactivity still applies when the law "imposes additional burdens based on conduct that occurred in the past").

${ }^{108} 533$ U.S. 289, 326 (2001); see also Kanstroom, supra note 56 at 413 ("Indeed, if there were a Nobel Prize for against-the-odds litigation, there could be little doubt that it should go to those who labored so long and hard to get the Court-finally-to affirm a few propositions that many had thought fundamental ....”).

${ }^{109}$ See Ponnapula v. Ashcroft, 373 F.3d 480, 492-93 (3d Cir. 2004) ("On the whole, we think the Supreme Court regarded St. Cyr as a clear and straightforward result flowing from Landgraf. . .."). The dissent in St. Cyr, written by Justice Scalia and joined by Chief Justice Rehnquist, Justice Thomas, and Justice O'Connor (in part), focused ex- 
time lag in correcting this clear error had serious consequences for the many legal permanent residents who were deported prior to St. Cyr without the opportunity to apply for the waiver of deportation to which the Supreme Court later determined they were entitled.

At its most basic, the portion of the St. Cyr decision devoted to retroactivity held that Mr. St. Cyr, who pleaded guilty to his crime before repeal of 212(c) relief, was still entitled to apply for a waiver of deportation. ${ }^{110}$ The St. Cyr decision begins by easily rejecting the two highly formalistic reasons given by the Justice Department and many lower courts for refusing to fully apply Landgraf to the immigration context. ${ }^{111}$ First, the Court held that just because deportation proceedings concern a future sanction does not mean that deportation cannot have a retroactive effect. ${ }^{112}$ Second, the Court quickly dispensed with

clusively on the jurisdictional question and never reached the retroactivity issue, even in dicta. St. Cyr, 533 U.S. at 326-47 (Scalia, J., dissenting). Given Scalia's insightful framing of retroactivity issues in Martin v. Hadix, 527 U.S. 343 (1998), and the forceful dissent by Justices Kennedy, Rehnquist, and Thomas in support of the presumption against retroactivity in Republic of Austria v. Altmann, 541 U.S. 677, 715-38 (2004), it would have been interesting to hear from the St. Cyr dissenters on the retroactivity issue. They might well have created a near unanimous decision on the retroactivity question.

${ }^{110}$ See INS v. St. Cyr, 533 U.S. 289, 314-26 (2001) (finding, based on Landgraf, no basis for retroactive removal of petitioner's access to 212(c) relief). The facts of St. Cyr are as follows. Enrico St. Cyr, a citizen of Haiti, was admitted to the United States as a lawful permanent resident in 1986, and pleaded guilty ten years later to a charge of selling a controlled substance, a violation of Connecticut law. Id. at 293. While this conviction made him subject to deportation, the AEDPA was not yet law at the time of his guilty plea, so he was eligible at the time of his plea to apply for 212(c) relief from deportation. Id. The INS began removal proceedings against St. Cyr on April 10, 1997, by which time both AEDPA and IIRIRA had become law. Id. The government argued that under the new statutes the Attorney General no longer had authority to consider 212(c) relief for St. Cyr, because his crime was an "aggravated felony" under the terms of the new laws. Id. at 297. The decision also included a highly contentious threshold question, namely whether despite AEDPA and IIRIRA's limits on habeas review of final orders of removal, federal district courts retained jurisdiction to hear habeas petitions. $I d$. at 309 . The court held that it did. Id. at 314 .

${ }^{111} I d$. at 324-25. These two arguments were (1) that the power to grant relief from deportation is an inherently prospective exercise; and (2) that immigrants who previously could apply for 212(c) were not guaranteed to actually win relief from deportation, because the relief was discretionary only; hence, removal of the ability to apply for relief does not amount to the impairment of a right. See In re Soriano, No. 3289, 1997 WL 33347804 (Att'y Gen. Feb. 21, 1997) (reporting a decision by Attorney General Reno that reversed a BIA opinion holding that the repeal of 212(c) was not retroactive).

${ }^{112}$ See St. Cyr, 533 U.S. at 324 (holding that even though deportation is a prospective undertaking, rather than punishment for a past criminal act, it can still be carried out in a way that is retroactive as to that act). The Court held in INS v. Lopez-Mendoza, 468 U.S. 1032, 1038-39 (1984), that deportation is prospective in the sense that it de- 
the claim, made by Attorney General Reno and many lower courts, that removal of discretionary relief does not constitute impairment of a right: "There is a clear difference, for the purposes of retroactivity analysis, between facing possible deportation and facing certain deportation." 113

The St. Cyr decision is important in three respects: (1) it mandates full application of the Landgraf framework to retroactivity questions in the immigration context; (2) like Landgraf and its progeny, it does not employ a subjective reliance test as part of step two of the analysis; and (3) it does not limit its decision to the facts of Mr. St. Cyr's case, that is to the context of an accepted plea bargain. Each issue is considered in turn below.

First, St. Cyr holds that the Court's well-established retroactivity jurisprudence, embodied in Landgraf and its progeny, applies as fully in the immigration context as in any other. ${ }^{114}$ Applying step one of the Landgraf analysis, the Court concluded that Congress did not clearly mandate the temporal reach of IIRIRA's repeal of 212(c) relief, and therefore the presumption against retroactivity meant the statute could not be applied in a way that caused a retroactive effect. ${ }^{115}$

Second, the Court does not employ an individualized assessment under step two of the Landgraf test. To determine whether the statute would cause a retroactive effect, the Court employs the classic Landgraf test: whether the new law would attach new legal consequences to

termines whether an immigrant will retain the right to remain in the United States, rather than punishing an immigrant for past bad acts. However, the Court only held that deportation was prospective as a way of concluding that deportation is not subject to the procedural protections of the criminal system. Id.; see also St. Cyr, 533 U.S. at 324 ("[W]e have [so held] in order to reject the argument that ... deportation proceedings are therefore subject to the "various protections that apply in the context of a criminal trial.'” (quoting Lopez-Mendoza, 468 U.S. at 1038)).

${ }^{113}$ St. Cyr, 533 U.S. at 325.

${ }^{114}$ See id. at $325 \mathrm{n} .55$ (asserting that just because Congress has the power to alter rights of permanent residents retroactively does not mean that the Court will not require Congress to "make its intention plain," as Landgraf mandates); see also Ponnapula v. Ashcroft, 373 F.3d 480, 491 n.7 (3d Cir. 2004) ("[T] he Court made plain in St. Cyr that the retroactive application of an immigration law is analyzed no differently from the retroactive application of any other civil statute." (citation omitted)). St. Cyr's holding put to rest the persistent argument that because immigrants are here at the "grace" of the Attorney General, laws pertaining to them do not need to follow settled retroactivity principles.

${ }^{115}$ See St. Cyr, 533 U.S. at 320 (concluding that there was no evidence that Congress had "affirmatively considered the potential unfairness of retroactive application and determined that it is an acceptable price to pay for the countervailing benefits" (internal quotation marks omitted) (quoting Landgraf v. USI Film Prods., 511 U.S. 244, 272-73 (1994))). 
past conduct. ${ }^{116}$ The Court did not ask whether Mr. St. Cyr, as an individual, would suffer a retroactive effect, but whether the class of immigrants who pleaded guilty to their crimes prior to the repeal of 212 (c) could, hypothetically, suffer a retroactive effect. ${ }^{117}$

The Court makes this inquiry because if any member of the larger class runs a hypothetical risk of having her expectations upset, then applying the new law to the past conduct of any class members would amount to the attachment of new legal consequences to past acts. ${ }^{118}$ This does not, however, mean that subjective individual reliance or actual class reliance is required. Under St. Cyr, as under Landgraf, the only test for retroactive effect is whether new legal consequences would be attached to past acts. ${ }^{119}$ The Court concludes that because plea agreements involve a quid pro quo exchange between defendants and the government, it is hypothetically possible (and even probable) that an immigrant defendant in that situation would consider the immigration consequences of pleading guilty. ${ }^{120}$

${ }^{116}$ See St. Cyr, 533 U.S. at 320 (explaining the second step of the analysis and citing to Landgraf for the standard).

117 The Court asks whether a retroactive effect would be caused by applying the new to law to "aliens who, like respondent, were convicted pursuant to a plea agreement at a time when their plea would not have rendered them ineligible for $\$ 212$ (c) relief." Id. at 320. The Third and Fourth Circuits have also recognized that St. Cyr establishes no subjective reliance test for a retroactive effect. See Olatunji v. Ashcroft, 387 F.3d 383, 388 (4th Cir. 2004) ("[W]e hold that reliance (whether subjective or objective) is not a requirement of impermissible retroactivity ...."); Ponnapula, 373 F.3d at 493 ("And indeed the Court's holding is not limited to those aliens who actually relied on the availability of $\S 212$ (c) relief ....”). In fact, Enrico St. Cyr himself did not negotiate a plea deal that absolutely guaranteed he would be eligible for 212(c) relief under the pre-1996 law, because his deal imposed a ten-year sentence, with suspension of that sentence after five years. See Brief for the Petitioner at 11 n.7, St. Cyr, 533 U.S. 289 (2001) (No. 00-767) (explaining the deal offered to Mr. St. Cyr). As the Third Circuit noted, if Mr. St. Cyr had actually served the entire five year sentence, under the pre-1996 law he would have been ineligible to apply for deportation relief under 212(c). See Ponnapula, 373 F.3d at 493 n.11 (noting that the pre-1996 INA denied 212(c) relief to immigrants who served a term of imprisonment of at least five years).

${ }^{118}$ As the Landgraf Court noted, " $\left.\mathrm{t}\right]$ he presumption against statutory retroactivity has consistently been explained by reference to the unfairness of imposing new burdens on persons after the fact." Landgraf, 511 U.S. at 270.

119 See St. Cyr, 533 U.S. at 321 (repeating Landgraf's formulation and Justice Story's definition of retroactivity).

${ }^{120}$ The Court notes the following:

Now that prosecutors have received the benefit of these plea agreements, agreements that were likely facilitated by the aliens' belief in their continued eligibility for $\S 212$ (c) relief, it would surely be contrary to "familiar considerations of fair notice, reasonable reliance, and settled expectations" to hold that IIRIRA's subsequent restrictions deprive them of any possibility of such relief. Id. at 323-24 (citation omitted) (quoting Landgraf, 511 U.S. at 270). Note that the 
Third, the St. Cyr decision does not limit its holding to the facts of the case, that is, to the context of an accepted plea bargain. The decision does discuss the specific reasons that the class of immigrants who accepted a plea deal could have hypothetically relied on the availability of 212(c) relief, thereby creating an impermissible retroactive effect. ${ }^{121}$ But it does not say that no other class of immigrant could hypothetically have so relied. ${ }^{122}$ This is important because many post-St. Cyr lower courts have confined St. Cyr to the plea bargain context. ${ }^{123}$ Lower courts have used this flawed understanding of St. Cyr's rule to reject retroactivity arguments made by other classes of immigrants without engaging in the required Landgraf two-step analysis. ${ }^{124}$ This violates St. Cyr's pronouncement that the Landgraf two-step analysis should be fully applied to immigration claims.

In summary, the flawed analysis that plagued 212(c) jurisprudence from Soriano until St. Cyr was based on the notion that immigration was somehow excused from normal retroactivity considerations. St. Cyr's major contribution was to correct this misperception. How-

Court here speaks only about a hypothetical immigrant within the class of immigrants who pleaded guilty to their crimes prior to repeal of 212(c) relief.

${ }^{121} I d$.

${ }^{122}$ See Ponnapula, 373 F.3d at 493 ("The holding in St. Cyr then is simply not subject to a qualification that the alien seeking the opportunity to pursue $\S 212$ (c) relief must have accepted a plea agreement that necessarily preserved his eligibility for $\S$ 212(c) relief ....").

${ }^{123}$ See infra Part II.B (describing lower courts' misapplication of St. Cyr).

${ }^{124}$ Courts have so held as to immigrants who turned down a plea agreement and proceeded to trial, and immigrants who committed their crimes prior to the repeal of 212(c). See, e.g., Montenegro v. Ashcroft, 355 F.3d 1035, 1037 (7th Cir. 2004) (per curiam) (denying the defendant 212(c) relief and holding that St. Cyr does not apply to defendants who elect to go to trial); Rankine v. Reno, 319 F.3d 93, 99-100 (2d Cir. 2003) ("The claim that they relied on $\S 212$ (c) relief . . is somewhat hollow; in fact, they decided to go to trial to challenge the underlying crime that could render them deportable and, had they succeeded, $§ 212$ (c) relief would be irrelevant."); Dias v. INS, 311 F.3d 456, 458 (1st Cir. 2002) (per curiam) (refusing \$ 212(c) relief because the petitioner, in going to trial, allegedly did not rely on the state of the law prior to AEDPA); Chambers v. Reno, 307 F.3d 284, 290 (4th Cir. 2002) ("The key event in terms of St. Cyr's analysis of whether the new statute would produce a retroactive effect was the alien's decision to abandon his constitutional right to a trial ...."); Armendariz-Montoya v. Sonchik, 291 F.3d 1116, 1121 (9th Cir. 2002) (rejecting an alien's claim to $\S 212$ (c) relief because he elected a jury trial); Brooks v. Ashcroft, 283 F.3d 1268, 1273-74 (11th Cir. 2002) (postulating that an immigrant's Sixth Amendment rights were not violated when he elected a jury trial, was convicted, and subsequently was not granted $\S 212$ (c) relief). Of these cases, those from the Second and Fourth Circuits held that non-plea convictions did not have a retroactive effect because they lacked the quid pro quo of a plea bargain; the other cases limited St. Cyr to the plea bargain context without specifically saying that $S t$. Cyr requires a quid pro quo for a finding of retroactive effect. 
ever, post-St. Cyr, many lower courts continue to insist that immigration cases need not conform to the Supreme Court's clear retroactivity jurisprudence.

\section{B. Post-St. Cyr: Lower Courts Continue to Misapply Landgraf}

The Second Circuit's decision in Rankine v. Reno is representative of many lower courts' failure to fully apply Landgraf's two-part test in the immigration context. ${ }^{125}$ That case resolved appeals by three permanent residents, two from Jamaica and one from Nigeria. ${ }^{126}$ All three committed their crimes and were convicted at jury trials before enactment of IIRIRA. ${ }^{127}$ The Rankine court adopted a faulty framework to decide whether an impermissible retroactive effect would occur by asking whether "the petitioners chose to go to trial in reliance on the availability of $\S 212$ (c) relief." ${ }^{\prime 28}$ This test improperly inquires into the subjective behavior of the parties rather than addressing whether the law would theoretically attach new legal consequences to the past acts of the class, as required by Landgraf. The second error in Rankine is that the court confined St. Cyr to its facts, namely the accepted plea bargain context, by distinguishing the acceptance of a plea bargain from the decision to go to trial. ${ }^{12}$

Third, the Rankine decision improperly shifts the burden of proof by turning the presumption against retroactivity into a protection that must be earned by the party that invokes it. Instead of the presumption governing the scope of the statute as to an entire class of immi-

125319 F.3d 93 (2d Cir. 2003).

${ }^{126} I d$. at $96-97$.

127 Id. at 97.

${ }^{128} I d$. at 100 (emphasis added). At various points in the decision, the court claims that a finding of retroactive effect requires that the immigrant's conduct indicate "reliance," $i d$. at 100; that she "detrimentally changed [her] position in reliance on continued eligibility for $\$ 212$ (c) relief," $i d$. at 99 ; that she can point to conduct "that reflects an intention to preserve [her] eligibility for relief under $\$ 212$ (c)," $i d$. at 100; that she engaged in some act that "gave rise to [a] reliance interest," $i d$;; that she can "plausibly claim that [she] would have acted ... differently if [she] had known about [the legal change]," $i d$. at 102 (quoting Armendariz-Montoya v. Sonchik, 291 F.3d 1116, 1121 (9th Cir. 2002) (internal quotation marks omitted)); and that she can show "detrimental reliance on $\$ 212$ (c) by ... [choosing] to go to trial," $i d$.

${ }^{129}$ The Rankine court held that "the choice to go to trial put[s] [the] petitioners on different footing [from an immigrant who accepts a plea bargain like Mr. St. Cyr] in two crucial respects," namely: (1) unlike St. Cyr, they did not "detrimentally change[ ] [their] position in reliance on continued eligibility for $\S 212$ (c) relief"; and (2) they "pointed to no conduct" that reflected "an intention to preserve their eligibility" for 212(c) relief. Rankine, 319 F.3d at 99-100. 
grants, as Landgraf requires, the Rankine court asked whether one particular member of that class has earned the right to be protected by the presumption. ${ }^{130}$ The "timeless and universal human appeal" ${ }^{131}$ of the antiretroactivity presumption is that it protects the people from government overreaching, honors a basic understanding about how the law works, protects groups from unfair targeting, and provides predictability. ${ }^{132}$ The purpose of the presumption is to protect classes of people from unfairness, a goal that would be undermined by requiring that individuals within that class do something to earn the right to be protected.

\section{Can Ponnapula and Olatunji Save Retroactivity Analysis in the Immigration Context?}

Two recent circuit court decisions may mark a return of 212(c) decisions to the Landgraf framework. Ponnapula $v$. Ashcroft, decided June 28, 2004, by a unanimous panel in the Third Circuit, held that an immigrant who turned down a plea agreement and proceeded to trial before the enactment of IIRIRA was entitled to apply for 212(c) relief. $^{133}$ On October 19, 2004, the Fourth Circuit concluded in Olatunji v. Ashcroft that "reliance is not a requirement of impermissible retroactivity." ${ }^{134}$ The Fourth Circuit decision, though it addressed a

${ }^{130}$ Indeed, the opinion does not once use the word "presumption" even though the presumption against retroactivity is at the very heart of this analysis. See Ponnapula v. Ashcroft, 373 F.3d 480, 489 n.6 (3d. Cir. 2004) (noting that the word "presumption" is used only one time in Rankine, and that it only appears incidentally "in an extended quotation of another Court of Appeals' decision").

${ }^{131}$ Kaiser Aluminum \& Chem. Corp. v. Bonjorno, 494 U.S. 827, 855 (1990) (Scalia, J., concurring); see also supra note 60 and accompanying text (discussing the longstanding principle that conduct should be adjudicated under the laws in effect at the time of the conduct).

${ }^{132}$ See supra notes $67-70$ and accompanying text (noting the policy concerns that animate the opposition to retroactive laws).

${ }^{133} 373$ F.3d 480, 483 (3d Cir. 2004) ("Here, with respect to an alien who reasonably could have relied on the potential availability of $\S 212$ (c) relief, application of the Landgraf principles shows that IIRIRA section 304(b) has an impermissible retroactive effect.").

${ }^{134} 387$ F.3d 383, 388 (4th Cir. 2004). The Olatunji decision involved a non-212(c) case arising under IIRIRA. Prior to IIRIRA, permanent residents who traveled abroad for "innocent, casual, and brief" trips were not considered, upon their return, to be applying for "entry" into the United States. See id. at 395 (quoting Rosenburg v. Fleuti, 374 U.S. 449, 461-62 (1963) (interpreting 8 U.S.C. \$ 1101(a)(13))). IIRIRA replaced the term "entry" with "admission" and applied IIRIRA to residents convicted of aggravated felonies who applied for "admission" when returning from brief trips abroad. See IIRIRA, Pub. L. No. 104-132, §301(a), 110 Stat. 546, 575 (1996) (codified as amended at 8 U.S.C. $§ 1101(\mathrm{a})(13)$ ) (defining "admission" to include permanent residents who 
different provision of IIRIRA, is remarkable for its spot-on treatment of the reliance question.

\section{The Third Circuit's Decision: Ponnapula}

The Third Circuit decision in Ponnapula offers an excellent rebuttal to the flawed post-St. Cyr thinking epitomized by the Rankine decision. The decision does three important things: (1) it takes statutory construction and the presumption against retroactivity as its starting point; (2) it challenges the Rankine claim that actual reliance is a prerequisite for applying the presumption against retroactivity in an individual case; and (3) it does not confine St. Cyr to the context of an accepted plea bargain.

Ponnapula involves a permanent resident who was a relatively minor (and perhaps completely unwitting) participant in a fraudulent loan application scheme. ${ }^{135}$ At the time of his trial he was offered a misdemeanor plea deal, but rejected it with the hope of being acquitted at trial, and also with the knowledge that 212(c) would be available to him should he be convicted. ${ }^{136}$ After his conviction, IIRIRA was enacted, which the government argued made him automatically deportable.

The Ponnapula court begins its analysis where Landgraf says it should, with statutory construction. ${ }^{137}$ Because Congress did not expressly mandate a retroactive repeal of 212(c), the court correctly notes that Landgraf established a "presumption against statutory retroactivity." 138 This starting point is a significant improvement over Rankine, which failed to even mention the existence of this presumption. $^{139}$

commit crimes of moral turpitude or drug offenses, travel abroad, and seek to return). When Mr. Olatunji returned from a nine-day trip to London, he disclosed his preIIRIRA conviction, and the government deemed him an alien seeking admission under IIRIRA, which subjected him to removal proceedings. See Olatunji, 387 F.3d at 386 (detailing the procedural aspects of Olatunji's case).

${ }^{135}$ See Ponnapula, 373 F.3d at 485 (noting the trial judge's finding that "petitioner's counsel has convinced me that his client was, for lack of a better term, the small fry or-maybe even better term-the schnook of this particular group of miscreants").

${ }^{136} I d$. at 484.

${ }^{137}$ See id. at 490 (" $[\mathrm{I}] \mathrm{n}$ the absence of a clear command, a consistent line of cases establishes that "congressional enactments and administrative rules will not be construed to have retroactive effect." (quoting Landgraf v. USI Film Prods., 511 U.S. 244, $272(1994)))$.

${ }^{138}$ Id. at 482 (quoting Landgraf, 511 U.S. at 270).

139 See supra note 130 and accompanying text (noting that Rankine does not discuss 
Second, after noting that the correct test under step two of Landgraf is to ask whether the new law "attaches new legal consequences to prior events," ${ }^{140}$ Ponnapula challenges Rankine's claim that the test for retroactive effect also requires proof of actual reliance. ${ }^{141}$ Reviewing the facts and holdings of Landgraf, Hughes, Martin, and St. Cyr, the court concludes that none of these cases require actual reliance by the party in order to benefit from the presumption against retroactivity. Ponnapula rightly criticizes Rankine for its "subtle heightening of the showing required to trigger the presumption against retroactivity." ${ }^{142}$

That said, Ponnapula does not reject reliance completely. Rather, the court concludes, based largely on Martin and St. Cyr, that the Supreme Court has adopted a "reasonable reliance" requirement as to the group or class of people "to whose conduct the statute is addressed." able reliance and requiring no reliance at all is meaningless. The Fourth Circuit in Olatunji makes this argument quite convincingly:

[W] e must admit that it is unclear to us in what circumstance, if any, the "reasonable reliance" inquiry will (or at least should) yield a conclusion different from that reached under Justice Story's framework. For it would seem never to be unreasonable for one to rely upon a duly enacted or promulgated law. ${ }^{144}$

While Ponnapula correctly rejects Rankine's requirement of actual reliance, the court muddies that clear conclusion by discussing $\mathrm{Mr}$. Ponnapula's "reasonable reliance." ${ }^{145}$ Because it is always reasonable

the presumption).

${ }^{140}$ Ponnapula, 373 F.3d at 482-83.

${ }^{141}$ Ponnapula correctly questions Rankine's focus on "the particular facts and circumstances of the party before the court." Id. at 491. "[T] he Second Circuit seems to require a quantum of evidence regarding the subjective intent of the party seeking to avoid retroactive application; this too strikes us as being in tension with the language of presumption in Landgraf and its progeny ...." Id.

${ }^{142} I d$. at 491.

${ }^{143} I d$. at 493.

144 Olatunji v. Ashcroft, 387 F.3d 383, 396 (4th Cir. 2004).

${ }^{145}$ For example, the Ponnapula court correctly emphasizes that the Supreme Court decided Landgraf and Hughes without reference to reliance by the parties or even the class:

[I]t is unlikely that in Landgraf any employer demonstrably relied on the absence of a punitive damages remedy for Title VII violations, or that in Hughes Aircraft any government contractor purposely arranged its billing practices $e x$ ante to take advantage of a specific defense under the False Claims Act.

Ponnapula, 373 F.3d at 493. Yet, having found that reliance was not a factor in either of these cases, the court nonetheless evaluates Mr. Ponnapula's situation in terms of his reliance. For example, the court says: 
to rely on the current state of the law, "reasonable reliance," can really only mean that a court applies the law as it existed at the time of the act. Thus, Ponnapula's holding is an affirmation of Landgraf's lack of a reliance requirement and a rejection of Rankine. But this clarity is undermined by the reliance language that the court uses. The Ponnapula analysis would be clearer if the language of "reasonable reliance" were substituted with a holding that no reliance at all is required to show retroactive effect. ${ }^{146}$ This is the conclusion that Olatunji reaches. ${ }^{147}$

Third, Ponnapula does not limit St. Cyr to the accepted plea bargain context. The decision correctly notes that St. Cyr should only be limited to its facts if St. Cyr "articulated the exclusive conditions for impermissible retroactivity in this context." ${ }^{148}$ Ponnapula concludes that this is not so: "St. Cyr is simply one application of the general principles articulated in Landgraf that counsel against interpreting statutes to have retroactive effect." ${ }^{49}$ Because St. Cyr gives one example of the way IIRIRA can attach new legal consequences to past acts, rather than giving the only way, the Ponnapula court is able to find an impermissible retroactive effect in a non-plea-bargain context.

This case may seem harder [than Landgraf and its progeny] because making the decision to go to trial is perhaps more complex and more nuanced, but we should not let that obscure the fact that former $\S 212$ (c) was one of a host of factors considered by aliens who elected that course .... Id. at 495 .

${ }^{146}$ One of the problems created by Ponnapula's use of the empty phrase "reasonable reliance" is that it sounds as though the court's no-reliance holding is limited by a reasonable reliance standard, when it really is not (because "reasonable reliance" can only mean reliance on the state of the law at the time of the conduct, which is the same as a no-reliance standard). The confusion created by this muddying manifests itself in the court's statement that it "highly doubt[s]" that immigrants who "went to trial because they were not offered a plea agreement" have a "reliance interest that renders IIRIRA's repeal of former $\S 212$ (c) impermissibly retroactive as to them." Id. at 494 . By suggesting that the court's holding does not apply to immigrants who were not offered a plea agreement because they lack a reliance interest, the court implies that its holding requires a showing of reliance, even though it arguably holds just the opposite of that.

${ }^{147}$ See Olatunji, 387 F.3d at 394 ("In sum, the historical presumption against retroactive application of statutes did not require reliance. Neither Landgraf nor subsequent Supreme Court authority imposes any such requirement.").

${ }^{148}$ Ponnapula, 373 F.3d at 488.

${ }^{149}$ Id. at 483. 


\section{The Fourth Circuit's Decision: Olatunji}

The Fourth Circuit's treatment of reliance in Olatunji v. Ashcroft provides an antidote to the confusion surrounding reliance in retroactivity analysis. ${ }^{150}$ The decision cuts through the chaff of previous decisions by flatly stating that reliance is not required for a finding of impermissible retroactive effect. ${ }^{151}$ The decision represents a fulfillment of one of St. Cyr's most important pronouncements-that retroactivity analysis is applied the same way in the immigration context as it is in any other area of civil law. ${ }^{152}$

The Olatunji case concerned a parallel IIRIRA provision that changed the rule for when permanent residents with criminal convictions were deemed admissible to the United States after returning from brief trips abroad. ${ }^{153}$ The respondent in the case, having pleaded guilty years earlier to one count of theft, was denied admission into the U.S. after a nine-day trip abroad, based on IIRIRA's redefinition of admissibility. ${ }^{154}$ The issue in the case was one of retroactivity: was an impermissible retroactive effect created by attaching new legal consequences (deportation) to a prior act (his crime and guilty plea)?

The Olatunji decision correctly calls cases like Rankine "nothing but judicial legislation," because they permit the retroactive application of a statute even though Congress did not mandate such retroactivity. ${ }^{155}$ Instead of adopting Rankine's flawed reasoning, Olatunji be-

${ }^{150} 387$ F.3d 383 (4th Cir. 2004).

151 . at 388.

${ }^{152}$ See supra note 114 and accompanying text (explaining that St. Cyr rejected lower court decisions holding that retroactivity analysis functioned differently in the immigration context).

${ }^{153}$ See supra note 134 and accompanying text for further explanation of the legal provisions at issue in Olatunji.

${ }^{154}$ The basic facts of Olatunji are as follows: Clifford K. Olatunji, a citizen of Nigeria, pleaded guilty in 1994 (pre-IIRIRA) to one count of theft of government property and was sentenced to two months at a community treatment center, a $\$ 259$ fine, a $\$ 2,296$ payment of restitution, and probation for two years. In 1998, after the enactment of IIRIRA, Mr. Olatunji took a nine-day trip to London. When he returned to the United States, he disclosed his conviction, which led the INS to classify him, according to IIRIRA, as a permanent resident seeking admission to the United States. Due to his conviction, he was deemed inadmissible under IIRIRA and was ordered deported. Olatunji, 387 F.3d at 386.

${ }^{155}$ See id. at 394 ("[W] here Congress has apparently given no thought to . . retroactivity whatever, there is no basis for inferring that Congress' intent was any more nuanced than that statutes should not be held to apply retroactively. Anything more, in the face of complete congressional silence, is nothing but judicial legislation."). 
gins its analysis with the retroactivity framework of Landgraf, namely statutory construction and the presumption against retroactivity. ${ }^{156}$

Directly rebutting the Rankine line of cases, Olatunji holds that "reliance (whether subjective or objective) is not a requirement of impermissible retroactivity." ${ }^{157}$ At most, the court says a "reasonable reliance" standard-à la Ponnapula - may be required; ${ }^{158}$ however, the Olatunji court views that as an empty requirement, given that it is always reasonable to rely on a "duly promulgated" law. ${ }^{159}$ The court notes that the Supreme Court's treatment of reliance has been "confusing . . beginning in Landgraf and continuing through St. Cyr." ${ }^{160}$ But after reviewing those cases, ${ }^{161}$ the court concludes that none established an actual reliance requirement. ${ }^{162}$

Requiring reliance, the Olatunji court argues, would not be in keeping with the logic of the presumption against retroactivity:

${ }^{156}$ See id. at 389 ("Retroactivity is a question of congressional intent.").

${ }^{157} I d$. at 388.

${ }^{158}$ See id. at 389 ("If some form of reliance were understood as required by the Supreme Court's teachings on the subject, it could only be objectively reasonable reliance.").

${ }^{159}$ See id. at 396 ("For it would seem never to be unreasonable for one to rely upon a duly enacted as promulgated law.").

${ }^{160} I d$. at 389. Olatunji also calls Landgraf's treatment of reliance "ambiguous." Id. at 390. This may be a bit of a false characterization, because the Landgraf Court forthrightly stated that fairness and reliance were not the basis for its decision. The Court found an impermissible retroactive effect because the compensatory damages "attach [ed] an important new legal burden to [the past] conduct," even though concerns about fairness and reliance were "muted." Landgraf v. USI Film Prods., 511 U.S. 244, 283 (1994). Therefore, Landgraf cannot be read to require any showing of reliance. The ambiguity of the Landgraf decision that the Olatunji court laments has been created by later interpretations of the decision, and particularly a misinterpretation of the "familiar considerations" phrase. See supra notes 102-04 and accompanying text (arguing that the circuit courts have rendered Landgraf's holding ambiguous by misreading one sentence of the Court's opinion).

${ }^{161}$ The Olatunji court's review of cases included Republic of Austria v. Altmann, 541 U.S. 677 (2004); Ponnapula v. Ashcroft, 373 F.3d 480 (3d Cir. 2004); Rankine v. Reno, 319 F.3d 93 (2d Cir. 2003); Chambers v. Reno, 307 F.3d 284 (4th Cir. 2002); INS v. St. Cyr, 533 U.S. 289 (2001); Velasquez-Gabriel v. Crocetti, 263 F.3d 102 (4th Cir. 2001); Tasios v. Reno, 204 F.3d 544 (4th Cir. 2000); Martin v. Hadix, 527 U.S. 343 (1998); Hughes Aircraft Co. v. United States ex rel. Schumer, 520 U.S. 939 (1997); and Landgraf, 511 U.S. at 244. Olatunji, 387 F.3d at 390-94.

${ }^{162}$ See Olatunji, 387 F.3d at 394 ("In sum, the historical presumption against retroactive application of statutes did not require reliance. Neither Landgraf nor subsequent Supreme Court authority imposes any such requirement. And we believe that the consideration of reliance is irrelevant to statutory retroactivity analysis."). The Ponnapula decision came to this same conclusion. See Ponnapula, 373 F.3d at 489 ("[T] he Supreme Court has never required actual reliance in any case in the Landgraf line.”). 
" $[$ S] ubjective reliance . . . is neither dictated by Supreme Court precedent nor related to the presumption of congressional intent underlying the bar against retroactivity." ${ }^{163}$ As Olatunji noted, retroactivity analysis is based on a statutory construction inquiry into the prescribed scope of the statute; once the scope is determined as to a class, the subjective behaviors of individual members of that class do not matter:

It is one thing to indulge in the supportable presumption that Congress intends its enactments not to operate retroactively; it is another altogether to indulge the quite different, and unsupported and unsupportable, presumption that Congress so intends, but only where the particular petitioning party can prove that he subjectively relied on the prior statement to his detriment.

Olatunji highlights the way in which Landgraf and retroactivity analysis generally are based on the notion of a separation of powers. Congress, not the courts, is the proper body to determine what is fair and unfair in terms of civil retroactivity, and whether unfairness is a worthy price to pay in order to accomplish other policy goals. ${ }^{165}$ If Congress has not mandated retroactive application, the courts cannot invade Congress' territory by judicially legislating a potentially unfair result. Only Congress can make that choice. Therefore, litigants, commentators, and courts confronted with civil retroactivity questions should focus on Landgraf's two-part test of statutory construction, rather than the legally irrelevant issues of individual fairness and notice. ${ }^{166}$ Unfairness arguments should be made to Congress, not the

163 Olatunji, 387 F.3d at 389.

164 Id. at 394. policy).

${ }^{65}$ See Landgraf, 511 U.S. at 280 (looking first to Congress for determination of

${ }^{166}$ For example, Mr. Ponnapula's story is incredibly sympathetic-he was a "small fry" in the criminal endeavor, taken advantage of by his brother; his crime was filing a false loan application; he had lived in the U.S. for many years and had a wife and children who were U.S. citizens; and he was at the very final stages of becoming a U.S. citizen, with just the oath left to be administered, when he was indicted. Ponnapula, 373 F.3d at 483-86. But suppose that none of that were true, and Mr. Ponnapula were actually an unsavory character who committed a violent crime. If he had turned down a plea deal, proceeded to trial, and received a sentence of less than five years he would still be eligible for 212(c) relief under the Olatunji holding and protected from retroactive application of IIRIRA, not because he deserved any special considerations because he was a good person, or because taking away 212(c) relief seemed "unfair," but simply because IIRIRA would attach new legal consequences to his previous act of rejecting the plea and proceeding to trial. 
courts, in this area of the law. Once Congress decides the temporal scope of a civil statute, the Courts must faithfully apply it. ${ }^{167}$

\section{THE COMMISSION OF THE CRIME IS THE RELEVANT ACT FOR DETERMINING THE RETROACTIVE EFFECT OF 212(C)'S REPEAL}

Given the Supreme Court's retroactivity framework, the commission of the crime should be the relevant act for considering whether application of IIRIRA's repeal of 212(c) is retroactive. Under such an analysis, if an immigrant committed her crime prior to passage of IIRIRA, she would still have access to 212(c) relief; if she committed the crime after IIRIRA's passage, she would not be eligible to apply for a waiver. To date, no circuit court has reached this conclusion.

In evaluating the question of whether the commission of the crime is the relevant past act for retroactivity purposes, no circuit court has rigorously applied the Supreme Court's retroactivity framework. Instead, the courts have rejected the argument out of hand by citing unsupported dicta from a Seventh Circuit decision that was issued prior to St. Cyr. ${ }^{168}$ This refusal to seriously examine the requirements of Landgraf and its progeny shows a continued reluctance to follow St. Cyr's command to apply retroactivity analysis uniformly across all areas of law, including the immigration context.

\section{A. The Circuit Courts Have Wrongly Rejected the Commission-of-the-Crime Argument}

The circuit courts have rejected the argument that the commission of the crime is the relevant act for determining retroactive effect on two grounds. First, courts have said that the conviction, not the underlying commission of the crime, is what renders the immigrant ineligible for 212(c) relief under IIRIRA. ${ }^{169}$ Therefore, the convic-

${ }^{167}$ The courts are, however, constrained at the margins by the Due Process Clause. See Morawetz, supra note 73, at 106 (suggesting that the Due Process Clause might render retroactive application of IIRIRA unconstitutional).

${ }^{168}$ See supra notes 105-08 and accompanying text (arguing that courts have confused Landsgraf's clear test by misreading one sentence in the opinion as authorizing reliance as a component of the test for retroactivity).

${ }^{169}$ See Domond v. INS, 244 F.3d 81, 85-86 (2d Cir. 2001) (" $[\mathrm{I}] \mathrm{t}$ is the conviction, not the underlying criminal act, that triggers the disqualification from $\S 212$ (c) relief." (internal quotation marks omitted) (quoting Mattis v. Reno, 212 F.3d 31, 37 (1st Cir. 2000))). 
tion, not the commission of the crime is the relevant act for retroactivity purposes. ${ }^{170}$

The second argument, actually more of a bald assertion offered with little explanation or support, is that criminals do not consider the immigration consequences of their crimes at the time of commission; therefore, the commission of the crime is not the proper point for retroactivity analysis. The most widely quoted version of this assertion comes from dicta in LaGuerre $v$. Reno, ${ }^{171}$ a pre-St. Cyr case from the Seventh Circuit. Judge Posner wrote for the court:

It would border on the absurd to argue that these aliens might have decided not to commit drug crimes, or might have resisted conviction more vigorously, had they known that if they were not only imprisoned but also, when their prison term ended, ordered deported, they could not ask for a discretionary waiver of deportation. ${ }^{172}$

Despite the fact that this dicta goes unexplained in LaGuerre, the statement has proven attractive to numerous courts. ${ }^{173}$ Decisions citing to LaGuerre's dicta as a shorthand way of rejecting a commission-

${ }^{170}$ Judge Gleeson, a district court judge in the Second Circuit, vehemently disagreed with the logic of Domond, though he conceded he was required to follow the precedent:

I suggest that common sense requires a different point of reference for the retroactivity analysis. Few people would disagree with [petitioner's] assertion that he has been ordered deported because he committed a property crime, not because he was convicted of it a year later. The new laws regarding deportation were intended to affect aliens who commit crimes, not judges or juries who pronounce them guilty. Mohammed v. Reno, 205 F. Supp. 2d 39, 46 (E.D.N.Y. 2002).

${ }^{171} 164$ F.3d 1035 (7th Cir. 1998). LaGuerre ultimately held, by a unanimous threejudge panel, that the district court did not have jurisdiction to hear petitioners' habeas claim due to the jurisdiction-limiting restrictions imposed by AEPDA. See id. at 1040 ("We conclude that for the class of aliens encompassed by section 440 (a), judicial review by means of habeas corpus did not survive the enactment of that section."). This holding, of course, was reversed when the Supreme Court decided St. Cyr four years later. Even though LaGuerre was overturned by the Supreme Court in St. Cyr and was written before St. Cyr confirmed that full Landgraf retroactivity analysis should be applied to immigration cases, lower courts continue to quote LaGuerre's dicta about the commission-of-the-crime argument. This alone is troubling.

${ }^{172} I d$. at 1041 .

${ }^{173}$ See, e.g., Mohammed v. Reno, 309 F.3d 95, 102 n.12 (2d Cir. 2002) (citing LaGuerre dicta); Domond v. INS, 244 F.3d 81, 86 (2d Cir. 2001) (same); Lara-Ruiz v. INS, 241 F.3d 934, 945 (7th Cir. 2001) (same); Mattis v. Reno, 212 F.3d 31 (1st Cir. 2000) (same); James v. Riley, 329 F. Supp. 2d 570 (E.D. Pa. 2004) (same). But see Mohammed v. Reno, 205 F. Supp. 2d 39, 43-46 (E.D.N.Y. 2002) (rejecting the dicta); Zgombic v. Farquharson, 89 F. Supp. 2d 220, 232, n.10 (D. Conn. 2000) (same), rev'd, 69 F. App'x 2 (2d Cir. 2003); Mojica v. Reno, 970 F. Supp. 130, 175 (E.D.N.Y. 1997) (same). 
of-the-crime claim usually fail to add any analytical meat to these very weak bones. ${ }^{174}$

There are two fundamental problems with the Seventh Circuit's "absurdity" rationale. First, given the Supreme Court's acceptance in Landgraf that businesses undertake cost-benefit analyses regarding their legal obligations, ${ }^{175}$ it is not absurd to imagine that immigrants might undertake a similar cost-benefit analysis before committing their own crimes.

Second, even if it is absurd that an immigrant would consider the immigration consequences of her criminal acts, the court is asking the wrong question. The issue for retroactivity analysis is not reliance on the state of the law at the time of the act, but whether the new law attaches new legal consequences to a past act. An immigrant's subjective consideration of the immigration consequences of her actions is not part of the retroactivity analysis-the immigrant does not have to prove she deserves the antiretroactivity presumption. It is therefore immaterial whether a subjective consideration is absurd or not.

Surprisingly, the LaGuerre dictum is embraced by the Third Circuit's decision in Ponnapula, even though Ponnapula rejects an actual

${ }^{174}$ For example, Lara-Ruiz, 241 F.3d at 945, dismisses the argument in half a paragraph, by citing LaGuerre's dicta and scoffing that the applicant cannot "seriously maintain" that IIRIRA's repeal of 212(c) "would upset his settled expectations sufficiently to trigger the presumption against retroactivity." The Lara-Ruiz court (1) relies solely on LaGuerre's dicta to reject the commission-of-crime argument, and (2) requires the immigrant to prove she deserves protection from the presumption against retroactivity, by proving that her expectations have been sufficiently upset to "trigger" protection of the presumption. The court is analytically superficial on the first count, and wrong on the second.

The Second Circuit offers only slightly more analysis in Mohammed $v$. Reno, 309 F.3d at 102, and relies on the LaGuerre "absurd" dicta as the basis for rejecting the claim. The court wraps the language of reliance around its conclusion of absurdity, which brings the decision into direct conflict with the Supreme Court's lack of a reliance requirement. See id. at 103 ("Mohammed, who was convicted after section 212(c) relief became unavailable, has no basis for claiming similar reliance."). Reliance is the wrong test for retroactivity, and even if it were the right test, it would hardly be absurd for an immigrant to be concerned about the immigration consequences of her actions. It was not absurd for USI Film, in Landgraf, to be concerned about the damages consequences of sexual harassment suits; and it was not absurd for Hughes Aircraft to be concerned about the mechanisms in place that might allow a private individual to sue the company for filing false claims. It seems no more absurd for an immigrant to be concerned about the immigration consequences of her contemplated crime.

${ }^{175}$ See Landgraf v. USI Film Prods., 511 U.S. 244, 283 n.35 (1994) ("The new damages provisions of $\S 102$ can be expected to give managers an added incentive to take preventive measures to ward off discriminatory conduct by subordinates before it occurs ...."). 
reliance requirement. ${ }^{176}$ Ponnapula justifies its acceptance of LaGuerre by attempting to draw a distinction between an "attenuated reliance interest" like the one it finds in Landgraf and Hughes (i.e., it was unlikely that USI Film Products would be faced with a sexual harassment suit or that Hughes Aircraft would be faced with a false claims suit) and an attenuation "connoting causal remoteness," which the court finds in the case of an immigrant. ${ }^{177}$ This attempt to distinguish the two cases is unconvincing. In each, the defendant is only vaguely aware of the potential consequences of its actions: USI Film did not know what kind of damages it faced if it were to commit sexual harassment; Hughes Aircraft was not aware of who could bring qui tam suits against it; and the immigrant might not be aware of exactly which crimes she can commit without risking the loss of a waiver of deportation. In addition, while many who commit crimes are aware that they will face legal and immigration consequences, it is also possible-as in Ponnapula - that they are such "small fries" in the operation that they are completely unaware that they will face criminal prosecution. This lack of awareness does not mean that retroactive consequences should be heaped upon such a person. Finally, Ponnapula's attempt to distinguish between different types of reliance contradicts that decision's core logic: that reliance is not a requirement for protection from retroactive laws.

\section{B. Which Past Act Is Relevant for Retroactivity Analysis?}

Step two of Landgraf asks whether new legal consequences would be attached to past acts. But which past acts are relevant for this retroactive effect analysis? Or, as Justice Scalia put the question in his concurrence in Martin v. Hadix, "retroactive in reference to what?"178

Both Landgraf and Hughes easily identify the relevant past act as the defendant's commission of the illegal action, rather than the defendant's conviction. And both cases state that the illegality of the past act-and the fact that the defendant was thereby on constructive notice not to commit such an act-is irrelevant to the decision of which act should be chosen. In the context of 212(c), however, the holdings of Landgraf and Hughes have not been followed. Lower court decisions like Lara-Ruiz and Mohammed have held that an immigrant's

${ }^{176}$ See Ponnapula v. Ashcroft, 373 F.3d 480, 495, 496 n.14 (quoting the LaGuerre claim of absurdity to reject the commission-of-the-crime argument).

${ }^{177} I d$. at 496 n. 14 .

${ }^{178} 527$ U.S. 343, 362 (1999) (Scalia, J., concurring). 
conviction is the relevant point of consideration because it is the conviction that makes the immigrant subject to deportation. ${ }^{179}$

In Landgraf, the Court could have chosen one of two acts as the "relevant conduct" for the retroactive effect test: either the commission of sexual harrassment against Ms. Landgraf or the trial court's finding that USI Film was guilty of committing sexual harassment (Point $A$ or $B$ of Figure 1). The Court chose Point $A$, asking whether the new damages provisions would attach new legal consequences to the commission of sexual harassment. ${ }^{180}$ The Court did not choose Point $B$, which would require asking whether new legal consequences would be attached to the court's finding that USI Film violated the law. One might defend the choice of Point $B$ because USI Film was not liable for damages until after an adjudication that the company was legally responsible for the sexual harassment; but the Court does not even consider this possibility. ${ }^{181}$ By not explaining why it chose $A$ over $B$, the Court leaves the impression that the harassment was so obviously the relevant conduct that the question did not warrant discussion.

Figure 1

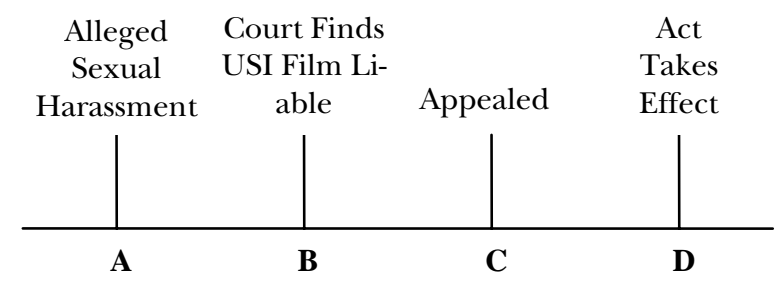

\footnotetext{
med).

180 See Landgraf v. USI Film Prods., 511 U.S. 244, 282 (1994) ("In this case, the event to which the new damages provision relates is the discriminatory conduct of respondents' agent....").

${ }^{181}$ Note that this logic parallels the argument made by lower courts in the immigration context, that the conviction is what makes immigrants eligible for deportation and therefore for 212(c) relief. See supra notes 169-70 and accompanying text (discussing the flawed logic of Domond $v$. INS, 244 F.3d 81, 85-86 (2d Cir. 2001), that the conviction is the crucial act). However, the Landgraf decision does not even mention the date on which the district court found that USI Film violated the law, showing that the Supreme Court did not even consider this argument.
}

${ }^{179}$ See supra note 174 and accompanying text (discussing Lara-Ruiz and Moham- 
Because Point $A$ is the relevant act, even if USI Film was not held liable until after the new law took effect (see Figure 2 for this scenario), the new law would still cause an impermissible retroactive effect as applied to the wrongful conduct. In other words, because the unlawful conduct is the relevant point of analysis, it does not matter whether the defendant's liability attaches before or after the change in the law.

Figure 2

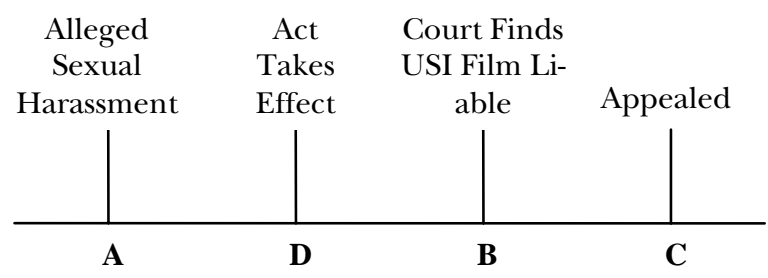

The Landgraf decision also rejected the plaintiff's argument that because intentional employment discrimination was illegal at the time of USI Film's conduct, attaching new damage consequences to these acts was not a retroactive penalty. The Court noted that just because the underlying conduct is "morally reprehensible or illegal," and the defendant should be on notice not to behave this way, that does not mean that unlimited consequences can be heaped retroactively on the guilty party absent a statement of congressional intent to do so. ${ }^{182}$ The Court also acknowledged that even where an action is illegal, a defendant company will not necessarily refrain from breaking the law; rather, a potential defendant might engage in a cost-benefit analysis of whether subjecting itself to liability would be worthwhile overall. ${ }^{183}$

182 Landgraf, 511 U.S. at 283 n.35.

${ }^{183}$ The Court acknowledged the possibility of this ex ante calculation by saying that the new damages provisions "can be expected to give managers an added incentive to take preventive measures to ward off discriminatory conduct . . before it occurs," $i d$. at 283 n.35, and can be expected to "have an impact on private parties' planning," $i d$. at 282 . 
The Court's reasoning in Hughes ${ }^{184}$ largely paralleled the Landgraf decision on the question of the relevant act for retroactivity analysis, analyzing the retroactivity question in reference to the alleged fraudulent conduct by the company. ${ }^{185}$ Like Landgraf, the Hughes Court also quickly rejected the argument that because the company's alleged conduct was illegal when it acted, it is permissible to expose it to increased liability under a new law. ${ }^{186}$

\section{The Martin v. Hadix Rules}

The Supreme Court's most instructive decision on the question of the relevant act for retroactivity analysis came in Martin v. Hadix. ${ }^{187}$ Martin involved ongoing attorneys' fees awarded to monitor compliance with a consent decree in a prison litigation case. ${ }^{188}$ Years after

184 Hughes Aircraft v. United States ex rel. Schumer, 520 U.S. 939 (1997). Recall that the issue in that case was whether a new provision, which permitted qui tam suits under the False Claims Act where the government previously possessed information about the alleged corruption, could be used to sue a company for conduct occurring before the date of the new provision's enactment. Id. at 941 .

${ }^{185}$ Though the Hughes Court declined to decide whether the relevant conduct was Hughes Aircraft's submission of the allegedly false claim or the company's financial disclosures to the government in the course of an audit, see id. at 946 n.4 ("Because both [acts] occurred prior to the effective date of the 1986 amendments, we need not address which of these two events constitutes the relevant conduct for purposes of our retroactivity analysis."), the Court's reasoning was focused on the possibility of an impermissible retroactive effect caused by changing the rules of qui tam suits after an alleged fraudulent violation has occurred, see id. at 945 (noting that " $[\mathrm{t}]$ he allegedly false claims at issue in this case were submitted by Hughes between 1982 and 1984"). See also id. at 948-49 (concluding that the illegality of the submission of false claims does not preclude a finding of impermissible retroactive effect); $i d$. at 948, 950 (arguing that the 1986 amendments do indeed create a new liability and a new cause of action for a company that is alleged to have submitted false claims); id. at 951 (holding that the 1986 amendments are not merely jurisdictional but impact whether a suit for submission of false claims "may be brought at all"). Nowhere in the decision did the Court analyze whether the amendments would be retroactive as applied to Hughes Aircraft's disclosure to the government. Thus, while the Court said it did not select which past conduct was relevant, all its analysis was focused squarely on the alleged crime committed by the defendant.

${ }^{186}$ See id. at 947 ("The same argument was made, and rejected, in Landgraf.").

${ }^{187} 527$ U.S. 343 (1999).

${ }^{188}$ The detailed facts and procedural posture of the case, located at Martin, 527 U.S. at 349-50, are as follows: The Martin case grew out of two successful class action suits brought by prisoners against the Michigan prison system in 1977 and 1980, under 42 U.S.C. $\$ 1983$. Id. at 347-52. The prisoners were successful in both actions, and the federal trial court ordered the semi-annual payment of attorneys' fees, at the prevailing market rate, for post-judgment monitoring of compliance with the court's decrees in both cases. By 1995 , the prevailing market rate for attorneys was $\$ 150$ per hour. The amount of the attorneys' fees payable to the prisoners' attorneys was brought into 
the fees were established, the Prison Litigation Reform Act (PLRA) set new fee structures that were lower than the amount originally awarded. ${ }^{189}$ The question before the Court was whether the new fee cap could be applied to cases where an ongoing attorneys' fee structure had already been put in place. The Justices unanimously agreed that the statute did not expressly authorize retroactive application of the new fee structure; however, this left the question of whether a retroactive effect would occur by applying the new law to past acts.

The major point of disagreement among the Justices involved what qualified as a "past act." As Justice Scalia pointed out in his concurrence, there were at least five separate points that could have been chosen as the relevant one: (1) the alleged violation that was the basis of the suit that gave rise to attorneys' fees; (2) the attorney's decision to bring the suit; (3) the filing of the suit; (4) the "doing of the legal work" that was the basis for the fees; or (5) the award by the court of attorneys' fees. ${ }^{190}$

Both the majority opinion and Justice Scalia's concurrence concluded that Point 4 was the relevant act, meaning that the fee cap could be applied to work done by the lawyers after passage of the new law, but not before. ${ }^{191}$ The majority reasoned that:

After April 26, 1996, any expectation of compensation at the pre-PLRA rates was unreasonable. There is no manifest injustice in telling an attorney performing postjudgment monitoring services that, going forward, she will earn a lower hourly rate than she had earned in the past. If the attorney does not wish to perform services at this new, lower pay rate, she can choose not to work. In other words, as applied to work per-

question by the enactment of the Prison Litigation Reform Act of 1995 (PLRA), Pub. L. No. 104-134, 110 Stat. 1321, on April 26, 1996. The PLRA contains various measures regulating (and often limiting) the conduct of prison litigation in the federal court system. At issue in Martin was section 803(d)(3) of the PLRA, codified at 42 U.S.C. $\$ 1997 \mathrm{e}(\mathrm{d})$ (1994), which capped attorneys' fees in prison litigation suits to no greater than $150 \%$ of the hourly rate permitted under federal law for court-appointed counsel. Because court-appointed attorneys in the Eastern District of Michigan were paid a maximum of $\$ 75$ an hour, the PLRA required payment of no more than $\$ 112.50$ for attorneys' fees in prison litigation suits in that district. Martin, 527 U.S. at 350.

${ }^{189}$ PLRA $\S 803(d)$ (amending 42 U.S.C. $\$ 1997$ ).

190 Martin, 527 U.S. at 362-63 (Scalia, J., concurring). The question at each of these five points would be whether the PLRA has a retroactive effect, that is, whether the PLRA's lower fee cap attached a new legal consequence to each of these past acts.

${ }^{191}$ See id. at 360 ("To impose the new standards now, for work performed before the PLRA became effective, would upset the reasonable expectations of the parties.”); $i d$. at 364 (Scalia, J., concurring) ("[T] he relevant retroactivity event is the doing of the work for which the incentive was offered."). 
formed after the effective date of the PLRA, the PLRA has future effect on future work; this does not raise retroactivity concerns. ${ }^{192}$

While the majority does not clearly state the decision rule that it adopts, the majority seems to select the point in time where the actor could choose to avoid all the consequences of the new law. ${ }^{193}$ On this basis, the Court rejects the prisoners' argument that the relevant act is the attorneys' filing of the cases in 1977 and 1980 (Point 2), because the argument wrongly assumes that "the attorney's initial decision to file a case on behalf of a client is an irrevocable one." ${ }^{194}$ In other words, the attorneys could still avoid the consequences of the PLRA by ceasing to work on the case once the new law was passed.

Interestingly, the dissent in Martin appears to adopt the same decisional rule as the majority, but finds that the parties could have avoided the consequences of the new law only at a much earlier point-at the time the attorneys chose to represent the prisoners (Point 2). ${ }^{19}$

The rule adopted by the majority and the dissent is based on the concern that when a party cannot avoid the consequences of a new law, attaching new consequences to prior acts would result in a manifest injustice. ${ }^{196}$ It is logical to draw this line based on injustice; after

${ }^{192} I d$. at 360 .

193 See id. at 358 ("The PLRA, as applied to work performed before its effective date, would alter the fee arrangement post hoc by reducing the rate of compensation. To give effect to the PLRA's fees limitations, after the fact, would 'attac[h] new legal consequences' to completed conduct." (quoting Landgraf v. USI Film Prods., 511 U.S. 244, 270 (1994))); see also Olatunji v. Ashcroft, 387 F.3d 383, 398 (4th Cir. 2004) (relying on the Martin holding to support the proposition that " $\mathrm{n}]$ otification is only relevant to the extent that it provides a party an opportunity to avoid future consequences").

${ }^{194}$ Martin, 527 U.S. at 361.

${ }^{195}$ See id. at 369 (Ginsburg, J., dissenting) ("Applying $§ 803(\mathrm{~d})$ to pending matters significantly alters the consequences of the representation on which the lawyer has embarked."). The dissent's adoption of the majority's rule is indicated by its statement that after the lawyers choose to bring the suits they have "little leeway to alter their conduct in response to the new legal regime." $I d$. On this point, Justice Ginsburg quotes approvingly from Judge Wald's dissent in Inmates of D.C. Jail v. Jackson, 158 F.3d 1357, 1362 (D.C. Cir. 1998): "[T] he triggering event for retroactivity purposes . . is when the lawyer undertakes to litigate the civil rights action on behalf of the client." Martin, 527 U.S. at 371 (Ginsburg, J., dissenting) (internal quotation marks omitted). Justice Ginsburg's conclusion is based on the ethical requirement that attorneys carry through their representation of clients to conclusion. See id. at 371 (citing MODEL Rules of Prof'L CONDUCT (1999) and MiCh. Rules of Prof'L CONDUCT (1999)).

196 Martin, 527 U.S. at 360 ("There is no manifest injustice in telling an attorney performing post-judgment monitoring services that, going forward, she will earn a lower hourly rate than she had earned in the past."); id. at 370 (Ginsburg, J., dissent- 
all, the reason our system has a presumption against retroactivity absent a clear congressional mandate is that we view retroactive laws as unjust.

The difficulty, of course, with simply adopting injustice or reliance as the rule for judging retroactive effect, as Justice Scalia notes in his concurrence, is that, "[i]n varying degrees," applying the new law to any of the five potential acts (Points A-E) would "frustrate expectations." ${ }^{197}$ Instead, he suggests the following helpful rule:

I think the decision of which reference point (which "retroactivity event") to select should turn upon which activity the statute was intended to regulate. If it was intended to affect primary conduct, [Point 1] should govern; if it was intended to induce lawyers to undertake representation, [Point 2] -and so forth. ${ }^{198}$

Justice Scalia takes a broad, common sense approach to determining the purpose of the PLRA. Acknowledging that "viewed in isolation" the purpose of the PLRA could be seen as "simply to prevent a judicial award of fees in excess of the referenced amount [Point 5],"199 Justice Scalia argues that the underlying purpose of the original statute, which the PLRA amended, was "to provide an appropriate incentive for lawyers to work on ... prisoner suits." ${ }^{200}$ The reference point, then, should be Point 4 , because the statute was focused on "the doing of the work" on prisoner cases. ${ }^{201}$

\section{The Martin Rules Applied to the 212(c) Context}

Under either of Martin's decisional rules, the relevant reference point in the 212(c) context is the commission of the crime. This can be demonstrated by applying Martin's two rules to a hypothetical 212(c) case in which the immigrant first committed a crime, was sub-

ing) ("There is scarcely greater injustice in denying pre-PLRA compensation for pretrial discovery in the one case than the other".).

${ }^{197}$ Id. at 363 (Scalia, J., concurring).

${ }^{198} I d$. Justice Scalia's concurrence in Martin reiterates the retroactive effect rule he suggested in his Landgraf concurrence, which was joined by Justices Kennedy and Thomas. See Landgraf, 511 U.S. at 291 (Scalia, J., concurring) ("The critical issue, I think, is not whether the rule affects 'vested rights,' or governs substance or procedure, but rather what is the relevant activity that the rule regulates. Absent clear statement otherwise, only such relevant activity which occurs after the effective date of the statute is covered.").

${ }^{199}$ Martin, 527 U.S. at 363.

${ }^{200} I d$.

${ }^{201} I d$. at 364. 
sequently convicted of the crime, and only then encounters IIRIRA's repeal of 212(c) relief.

Under the rule adopted by both the majority and dissent in Martin, our hypothetical court would ask, "At what point in time could an immigrant have ensured that she would have avoided the consequences of IIRIRA's repeal of 212(c)?" The answer is that she could only ensure that she would not be subject to IIRIRA's elimination of the discretionary waiver at the time she committed the crime. Once she commits her crime, she cannot ensure that she will avoid conviction, and, therefore, IIRIRA's repeal of 212(c).

In contrast, under Justice Scalia's proposed rule from Martin, our court would ask: "What was the purpose of the new law, and what actions was it intended to regulate?" In the narrow sense, it could be said that IIRIRA's repeal of 212(c) was intended to ensure the deportation of those immigrants who had been convicted of aggravated felonies. But, following Justice Scalia's admonition to look at the broader, common sense purpose of the original act, it seems that repealing the waiver was intended to regulate primary conduct in two ways: first, by providing a disincentive for immigrants to commit certain crimes, and second, to remove certain types of immigrant law-breakers from the United States. The driving force behind repeal is not to deport people who courts have labeled as aggravated felons, but to deport people who pose a danger to society because they have committed certain crimes. $^{202}$ It is not their conviction for crimes that causes concern about their presence in the United States, but the fact that they committed certain crimes at all. Therefore, it would be impermissibly retroactive to attach the new legal consequence of the repeal of 212(c) to immigrants who committed their crimes prior to the enactment of IIRIRA.

In summary, under either decisional rule offered in Martin, and under the holdings of both Landgraf and Hughes, the commission of the crime is the relevant point of analysis for 212(c) retroactivity decisions. Despite St. Cyr's command that retroactivity analysis should fully apply in the immigration context, the lower courts have generally not accepted the commission-of-the-crime argument. ${ }^{203}$ The few

${ }^{202}$ See, e.g., Mohammed v. Reno, 205 F. Supp. 2d 39, 46 (E.D.N.Y. 2002) ("Few people would disagree with [petitioner's] assertion that he has been ordered deported because he committed a property crime, not because he was convicted of it a year later.").

${ }^{203}$ See supra Part III.A (discussing the rule that the relevant event for retroactivity analysis is not commission but conviction). 
courts that have undertaken a full analysis of the retroactive effect in reference to the commission of the crime have concluded that the commission of the crime is the relevant event. ${ }^{204}$ But those cases have been universally overturned on appeal, and no circuit currently holds that the commission of the crime is the relevant act for retroactive effect analysis. ${ }^{205}$

\section{E. A Persistent Refusal To Apply Landgraf?}

While the courts have easily viewed the commission of the crime as the relevant reference point for cases involving corporate wrongdoers like USI Film and Hughes Aircraft, they have refused to do so in the case of immigrant wrongdoers. Perhaps courts find the notion of immigrants contemplating the costs of individual crime-be it white collar crime (as in Ponnapula) or street crime (as in St. Cyr), beyond the pale, even absurd. Yet, both Landgraf and Hughes forcefully rejected the notion that normal retroactivity rules do not apply if the underlying activity is illegal.

This willingness of courts to apply one set of retroactivity rules to most retroactivity cases and another set to retroactivity cases involving immigrants is the sort of incongruity that St. Cyr was supposed to put an end to. With Ponnapula and Olatunji helping to return 212(c) retroactivity analysis to the framework of Landgraf, it is possible that lower courts will engage the commission-of-the-crime argument. At the very least, courts should seriously analyze the proposition, cease relying on the LaGuerre dicta, and systematically consider the Landgraf, Hughes, and Martin holdings as applied to the 212(c) context.

\section{CONCLUSION}

The recent circuit court decisions in Ponnapula and Olatunji offer hope that retroactivity analysis in the immigration context will finally conform to the framework of Landgraf and its progeny. While the Supreme Court's landmark decision in St. Cyr required full application of retroactivity analysis in the immigration context, ${ }^{206}$ the lower courts have largely failed to follow this dictate.

204 Id

205 See supra note 124 and accompanying text (listing circuit court decisions that limit St. Cyr to the plea bargain context).

206 See INS v. St. Cyr, 533 U.S. 289, 324 (2000) (rejecting the INS argument that "application of the law of deportation can never have a retroactive effect"). 
Instead the lower courts have continued to ignore the clear framework of Landgraf and its progeny: (1) retroactivity analysis fundamentally involves statutory construction-an inquiry into the congressionally-mandated scope of the statute as to an entire class, not into individual, subjective reliance on the prior state of the law; (2) unfairness and the potential for reliance on the current state of the law are the reasons for the strong presumption against retroactivity, rather than the test for a retroactive effect; and the presumption against retroactivity is not a right to be earned by individuals, but a protection granted to all members of the class; (3) if Congress did not expressly mandate retroactive application of a statute, there is a presumption against retroactivity and a court may not permit any application that would cause a retroactive effect; to do otherwise would be nothing less than judicial legislation; (4) a retroactive effect occurs when a new law attaches new legal consequences to past acts; and (5) determining which past acts are relevant for the retroactive effect inquiry requires a clear test. The majority and dissent in Martin ask at what point a party could ensure it would not be subject to any of the new law's consequences; Scalia's concurrence suggests asking what the purpose of the statute is and what conduct it seeks to regulate. Under either of Martin's decisional rules, the relevant event for analysis of a retroactive effect in the 212 (c) context is the commission of the underlying crime.

Following repeal of 212(c) relief in 1996, it took six years of misdirected decisions before the Supreme Court in St. Cyr ordered lower courts to fully apply its retroactivity jurisprudence to the immigration context. During those six years, many permanent residents were summarily deported without their rightful opportunity to apply for a waiver of deportation. Today, because the lower courts continue to incorrectly apply the retroactivity framework in 212(c) cases, permanent residents who committed their crime or turned down a plea offer and proceeded to trial before passage of IIRIRA continue to be denied the right to apply for the waiver of deportation to which they are entitled.

Hopefully, the recent decisions in the Third and Fourth Circuits will encourage other circuits to revisit their 212(c) decisions and fully apply Landgraf to these cases. To do less results in just the unfairness, overreaching, and judicial legislation that the presumption against retroactivity was designed to prevent. 